\title{
III. Index of Articles by Author
}

Abegglen, H. and Abegglen, J.-J.: Field Observation of a Birth in Hamadryas Baboons. 26 (1): 54-56 (1976).

Abegglen, J.-J.: vide Abegglen, H. (1976).

Abplanalp, P.: The Neuroanatomical Organization of the Visual System in the Tree Shrew. 16 (1-2): 1-34 (1971).

Adam, K.R.: vide Butler, H. (1964).

Adey, W.R.: vide Freemon, F.R. (1970).

Ahmed, M.: vide Kanagasuntheram, R. (1970).

Ahmed, M. M.: Microscopic Anatomy and the Attenuation of Elastic Tissue in the Aortic Wall of Slow Loris (Nycticebus coucang coucang). 8 (3-4): 290-300 (1968).

Alcalá, J.R. and Conaway, C.H.: The Gross and Microscopic Anatomy of the Uterus masculinus of Tree Shrews. 9 (3-4): 216-245 (1968).

Al-Doory, Y.: The Mycoflora of the Subhuman Primates. III. The Flora of the Skin of the Baboon, Vervet, and Gelada in Captivity. 7 (3-4): 292-298 (1967).

Aldrich-Blake, F.P. G.: A Fertile Hybrid Between Two Cercopithecus spp. in the Budongo Forest, Uganda. 9 (1): 15-21 (1968).

-: vide Goss-Custard, J. D. (1972).

-: videCHГVERS, D.J.(1975).

Aldrich-Blake, F.P.G.; Bunn, T.K.; Dunbar, R.I.M., and Headley, P.M.:

Observations on Baboons, Papio anubis, in an Arid Region in Ethiopia. 15 (1-2): 1-35 (1971). Aldrich-Blake, P.: vide Crook, J.H. (1968).

Alexander, B. K. and Bowers, J. M.: Social Organization of a Troop of Japanese Monkeys in a Two-acre Enclosure. 10 (3): 230-242 (1969).

Allen, M.L.: vide Lemmon, W.B. (1978).

Allen, R.C. and Buettner-Janusch, J.: Red Cell and Serum Proteins of Patas Monkeys,

Cercopithecus ( = Erythroce-bus) patas. 20 (5-6): 321-330 (1973).

Alper, C. A.: videHrdy, D.B. (1975).

Altner, G.: Histologische und verglei-chend-anatomische Untersuchungen zur Ontogenie und Phylogenie des Hand-skeletts von Tupaiaglis (Diard 1820) und Microcebus murinus (J.F.

Miller, 1777). 14(Suppl.): 1-106(1971).

Ambrus, J.L.: vide Huang, C.C. (1969).

Ananthakrishnan, R.: vide McDerm $\gamma$ d, E.M. (1972).

Anderson, A.: vide Doyle, G. A. (1969).

-: vide Doyle, G. A. (1971).

Anderson, CO.: vide Lorenz, R. (1973).

Andrews, P.: vide Whybrow, P. J. (1978).

Andrews, P. and Simons, E.: A New African Miocene Gibbon-Like Genus, Den-dropithecus (Hominoidea, Primates) with Distinctive Postcranial Adaptations: Its

Index of Articles by Author 
Significance to Origin of Hylobatidae. 28 (3): 161-169 (1977).

Angst, R.: Über die Variabilität und Ver-änderung der präbasialen Kyphose wäh-rend der postnatalen Ontogenese bei Colobinenschädeln. 8 (3-4): 301-306 (1968).

Angst, R. und Mann, P.: Zur Variabilität von Urogale everetti. 15 (1-2): 148-158 (1971). Angst, W. and Thommen, D.: New Data and a Discussion of Infant Killing in Old World Monkeys and Apes. 27 (3): 198-229 (1977).

Angus, S.: Water-Contact Behavior of Chimpanzees. 14 (1-2): $51-58$ (1971).

Ankel, F.: Der Canalis sacralis als Indika-tor für die Länge der Caudalregion der Primaten. 3 (4): 263-276 (1965).

Anschel, S.: vide Talmage-Riggs, G. (1973).

Anschel, S. and Talmage-Riggs, G.: Social Organization of Captive Monan-drous Squirrel Monkey Groups (Saimiri sciureus). 28 (3): 203-215 (1977).

Antonius, J.I.; Ferrier, S.A., and Dil-lingham, L.A.: Pulmonary Embolus and Testicular Atrophy in a Gorilla. 15 (3-4): 277-292 (1971).

Arnold, R.C.: vide Rumbaugh, D.M. (1971).

Arnold, R. C. and Rumbaugh, D. M.: Extinction : A Comparative Primate Study of Lemur and Cercopithecus. 14 (3-4): 161-170(1971).

Ausmann, L. M.: vide Samonds, K.W. (1974).

Ausman, L.M.; Gallina, D.L.; Hayes, K.C., and Hegsted, D.M.: Hematol-ogical Development of the Infant Squirrel Monkey (Saimiri sciureus). 26 (4): 292-300(1976).

Ayats, H.: vide Bert, J. (1967).

Baker, C.A. and Hendrickx, A.G.: The

Number of Umbilical Vessels in the

Squirrel Monkey (Saimiri sciureus). 27 (3): 230-233 (1977).

Baldwin, D. V. and Suomi, S. J.: Reactions of Infant Monkeys to Social and Non-social

Stimuli. 22 (4): 307-314 (1974).

Baldwin, J.D.: The Social Behavior of Adult Male Squirrel Monkeys (Saimiri sciureus) in a Semi-natural Environment. 9 (3-4): 281-314 (1968).

-: The Ontogeny of Social Behaviour of Squirrel Monkeys (Saimiri sciureus) in a Seminatural Environment. 11 (1-2): 35-79 (1969).

-: The Social Organization of a Semifree-Ranging Troop of Squirrel Monkeys (Saimiri sciureus) 14 (1-2): 23-50 (1971).

Baldwin, J.D. and Baldwin, J.I.: The Ecology and Behavior of Squirrel Monkeys (Saimiri oerstedi) in a Natural Forest in Western Panama. 18 (3-4): 161-184(1972).

-: Interactions between Adult Female and Infant Howling Monkeys (Alouatta pal-liata). 20(1): 27-71 (1973).

-: Vocalizations of Howler Monkeys (Alouatta palliata) in Southwestern Panama. 26 (2): 81 108 (1976).

Baldwin, J.I.: vide Baldwin, J.D. (1972).

-: vide Baldwin, J.D. (1973).

-: vide Baldwin, J.D. (1976).

Balzano, E.: vide Bert, J. (1972).

Balzano, E.; Guillon, R.; Forni, C; Fady, J.C. et Bert, J.: Modifications du comportement du babouin Papio papio dans son milieu naturel par l'ap-port d'aliments. 19 (5): 404-408 (1973). 
Barfield, M. A.: vide Fitz-Gerald, F. L. (1970).

Barnicot, N.A.: vide Jolly, C.J. (1966).

-: videHRDY, D.B. (1975).

Barnicot, N. A. and Hewett-Emmett, D.: Red Cell and Serum Proteins of Tala-poin, Patas and Vervet Monkeys. 15 (1-2): 65-76 (1971).

-: Red Cell and Serum Proteins of Cerco-cebus, Presbytis, Colobus and Certain

362

A Topical Guide to 'Folia Primatologica'

Other Species. 17 (5-6): 442-457 (1972).

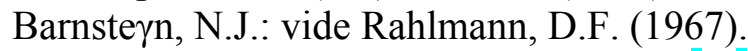

Barrow, M.V.; Steffek, A.J., and King, C. T. G.: Thalidomide Syndrome in Rhesus Monkey

(Macaca mulatta). 10 (3): 195-203 (1969).

Bashir-Farahmand, J.: vide McArthur, J.W. (1972).

Battie, C: vide Green, R. (1972).

Beard, M. E. J.: vide Huser, H.-J. (1969).

Beard, M.E.J. and Huser, H.-J.: Studies on Folate and Vitamin B12 Metabolism in Primates.

II. Vitamin B12 Binding Proteins. 12 (4): 305-312 (1970).

Bearder, S.K.: vide Doyle, G.A. (1969).

-: vide Doyle, G.A.(1971).

-: vide Pinto, D. (1974).

Behar, I. and Bock, P.D.: Visual Acuity as Function of Wavelength in Three Catar-rhine Species. 21 (3-4): 277-289 (1974).

Bekker, T.: vide Doyle, G.A. (1967).

Benirschke, K.: vide Low, J. R. (1968).

-: vide Bogart, M.H. (1977).

Benirschke, K. and Bogart, M. H.: Chromosomes of the Tan-Handed Titi (Cal-licebus torquatus, Hoffmannsegg, 1807). 25(1): 25-34 (1976).

Benirschke, K. and Layton, W.: An Early Twin Blastocyst of the Golden Lion Marmoset,

Leontocebus rosalia L. 10 (1-2): 131-138 (1969).

Benjamin, S.A.: vide Brumback, R.A. (1971).

Bergeron, J.A. and Buettner-Janusch, J.: Hematology of Prosimian Primates: Galago, Lemur and Propithecus. 13 (2-3): 155-165 (1970).

-: Hematology of Prosimian Primates. II. A Comparative Study of Lemuriformes in Captivity in Madagascar and North Carolina. 13 (4): 306-313 (1970).

Berkson, G.: Defective Infants in a Feral Monkey Group. 12 (4): 284-289 (1970).

Bernor, R.: vide Suarez, B.K. (1972).

Bernstein, I. S.: The Integration of Rhesus Monkeys Introduced to a Group. 2 (1):

50-63 (1964).

-: Activity Patterns in a Cebus Monkey Group. 3 (2-3): 211-224 (1965).

-: Intertaxa Interactions in a Malayan Primate Community. 7 (3-4): 198-207 (1967).

-: Social Status of two Hybrids in a Wild Troop of Macaca irus. 8 (2): 121-131 (1968).

-: Introductory Techniques in the Formation of Pigtail Monkey Troops. 10(1-2): 1-19 (1969).

-: Activity Patterns in Pigtail Monkeys Groups. 12 (3): 187-198 (1970).

-: Daily Activity Cycles and Weather Influences on a Pigtail Monkey Group. 18 (5-6): 390415 (1972). 
-: Activity Patterns in a Gelada Monkey Group. 23 (1-2): 50-71 (1975).

-: Activity Patterns in a Sooty Mangabey Group. 26 (3): 185-206 (1976).

Bernstein, I.S.; Gordon, T.P., and Rose, R.M.: Aggression and Social Controls in Rhesus Monkey (Macaca mulatta) Groups Revealed in Group Formation Studies. 21 (2): 81-107 (1974).

Bernstein, I.S. and Schusterman, R.J.: The Activity of Gibbons in a Social Group. 2 (3): 161170 (1974).

Bert, J.: vide Balzano, E. (1973).

Bert, J.; Ayats, H.; Martino, A. et Collomb, H.: Le sommeil nocturne chez le babouin Papio papio. Observations en milieu naturel et données électrophysio-logiques. 6 (1-2): 28-43 (1967).

-: Note sur Torganisation de la vigilance sociale chez le babouin Papio papio dans l'Est Sénégalais. 6 (1-2): 44-47 (1967).

Bert, J. et Collomb, H.: Etude électro-encéphalographique de deux cynomor-phes de $\Gamma$ Ouest Africain. 1 (3-4): 137- 149 (1963).

Bert, J. et Pegram, V.: L'électroencéphalo-gramme du sommeil chez les Cercopi-thecinae: Erythrocebus patas et Cerco-pithecus aethiops sabaeus. 11 (1-2: 151- 159 (1969).

Index of Articles by Author

363

Bert, J.; Pegram, V. et Balzano, E.: Com-paraison du sommeil de deux macaques (Macaca radiata et Macaca mulatta). 17 (3): 202-208 (1972).

Bertrand, M.: vide Hunkeler, C. (1972).

-: vide Faucheux, B. (1978).

Bibus, E.: Kraniometrische Untersuchun-gen an Co/oẁwí-Schädeln. 6 (1-2): 92-130(1967).

Biegert, J.: Adolph H. Schultz. Zum Tod des Zürcher Anthropologen. 26 (1): 2-4 (1976).

Biegert, J. und Maurer, R.: Rumpfske-lettlänge, Allometrien und Körperpro-portionen bei catarrhinen Primaten. 17 (1-2): 142-156(1972).

Binns, R. and Clark, G. C.: Lung Function in Cynomolgus Monkeys and Baboons. 17 (3): 209-217 (1972).

Blakley, G. A.: Luteinizing Hormone Levels in Nonhuman Primates. 13 (4): 298-305 (1970).

Bleby, J.: vide Turton, J.A. (1978).

Blitz, J.: vide Ploog, D. W. (1963).

Boelkins, R. C.: vide Hall, K. R. L. (1965).

Bock, P.D.: vide Behar, I. (1974).

Bogart, M.H.: vide Benirschke, K.: (1976).

Bogart, M.H. and Benirschke, K.: Chromosomal Analysis of the Pygmy Chimpanzee (Pan paniscus) with a Comparison to Man. 27 (1): 60-67 (1977).

Bogart, M.H. and Kumamoto, A.T.: Karyotype Abnormalities in Two Primate Species, Pygathrix nemaeus and Lemur coronatus. 30(2): 152-160(1978).

Bogart, M.H.; Kumamoto, A.T., and Lasley, B.L.: A Comparison of the Reproductive Cycle of Three Species of Lemur. 28 (2): 134-143 (1977).

Bone, E.L.: Les chances primatologiques de l'Est-Africain. 2(1): 1-21 (1964).

Booth, S.N. and Freedman, L.: Multi-variate Discriminant Analysis Applied to Cranial

Features oîPapio ursinus and P.cynocephalus. 12 (4): 296-304 (1970).

Boskoff, K. J.: Aspects of Reproduction in 
Ruffed Lemurs (Lemur variegatus). 28 (4): 241-250 (1977).

-: videEAGLEN, R.H. (1978).

Bosman, A. R.: vide Brink, A. J. (1970).

Bosu, W.T.K.; Johansson, E.D.B., and Gemzell, C.: Ovarian Steroid Patterns in Peripheral Plasma during the Menstrual Cycle in the Rhesus Monkey. 19 (2-3): 218-234(1973).

Bourlière,: vide Petter-Rousseaux, A. (1965).

-: vide Hunkeler, C. (1972).

-: vide Faucheux, B. (1978).

Bourlière, F. et Petter-Rousseaux, A.: Existence probable d'un rythme méta-bolique saisonnier chez les Cheirogalei-nae (Lemuroidea). 4 (4): 249-256 (1966).

Bousset, J.: vide Hladik, CM. (1971).

Bowden, D.: Primate Behavioral Research in the USSR. The Sukhumi Medico-Biological Station. 4 (5): 346-360 (1966).

Bowden, D.; Winter, P., and Ploog, D.: Pregnancy and Delivery Behavior in the Squirrel

Monkey (Saimiri sciureus) and Other Primates. 5 (1-2): 1-42 (1967).

Bowers, J.M.: vide Alexander, B.K. (1969).

Bowman, R. E.: vide Chamove, A. S. (1976).

Bown, T. M.: Affinities of Teilhardína (Primates Omomyidae) with Description of a New Species from North America. 25 (1): 62-72 (1976).

Bown, T.M. and Gyngerich, P.D.: The Paleocene Primate Plesiolestes and the Origin of Microsyopidae. 19 (1): 1-8 (1973).

Bown, T.M. and Rose, K.D.: New Early Tertiary Primates and a Reappraisal of some Plesiadapiformes. 26 (2): 109-138 (1976).

Brehme, H.: Uatersuchungen am Haut-leistensystem der Palma und Planta von Colobus polykomos, Colobus badius, Co-lobus verus und Nasalis larvatus. 6 (3-4): 243-283 (1967). -: Zur Variabilität des Hautleistensystems der Meerkatzen (Cercopithecus) und 364

A Topical Guide to 'Folia Primatologica'

des Husarenaffen (Erythrocebus patas). 9(1): 41-67 (1968).

Brehme, H. und Wiersema, H.D.: Finger-und Zehenbeerenmuster von Pongiden. 20(5-6): 391-409(1973).

Brett, I.J.: vide Harnes, D.E. (1971).

Breuggeman, J.A.: Parental Care in a Group of Free-Ranging Rhesus Monkeys (Macaca mulatta). 20 (2-3): 178-210(1973).

Brink, A.J.; Lewis, CM.; Bosman, A.R., and Lochner, A.: The Baboon (Papio ursinus) Heart (Coronary Blood Supply, Muscle Function and Metabolism). 13 (1): 11-22(1970).

Broadhurst, P. L. and Jinks, J. L.: Parity as a Determinant of Birth Weight in the Rhesus Monkey. 3 (2-3): 201-210 (1965).

Bronsdon, M. A.: vide Dillingham, L.A. (1971).

Brooks, B.A.: vide Randolph, M.C. (1967).

Brouwer, J.N.: vide Glaser, D. (1978).

Brown, K. and Mack, D. S.: Food Sharing among Captive Leontopithecus rosalia. 29 (4): 268-290 (1978).

Brumback, R.A.; Staton, R.D.; Benjamin, S.A., and Lang, CM.: The Chromosomes of Aotus trivirgatus Humboldt 1812. 15 (3-4): 264-273 (1971). 
Brumback, R.A. and Willenborg, D.O.: Serotaxonomy of Aotus. A Preliminary Study. 20(23): 106-111 (1973).

Bryan, D.: vide Candland, D.K. (1973).

Buettner-Janusch, J.: Hemoglobins and Transferrins of Baboons. 1 (2): $73-87$ (1963).

-: The Breeding of Galagos in Captivity and Some Notes on their Behavior. 2 (2): 93-110 (1964).

-: A Problem in Evolutionary Systematics: Nomenclature and Classification of Baboons, Genus Papio. 4 (4): 288-308 (1966).

-: vide Nute, P.E. (1968).

-: vide Nute, P.E. (1969).

-: vide Coppenhaver, D. (1970).

-: vide Bergeron, J. A. (1970).

-: vide Allen, R.C (1973).

Buettner-Janusch, J.; Buettner-Janusch, V., and Coppenhaver, D.: Properties of the

Hemoglobins of Newborn and Adult Prosimians (Prosimii: Lemuriformes and Lorisiformes). 17 (3): 177-192 (1972).

Buettner-Janusch, J. and Wiggins, R. C.: Haptoglobins and Acid Phosphatases of Galago. 13 (2-3): 166-176 (1970).

Buettner-Janusch, V.: vide Nute, P.E. (1969).

-: vide Buettner-Janusch, J. (1972).

Buikstra, J.E.: Healed Fractures in Macaca mulatta: Age, Sex, and Symmetry. 23 (1-2): 140148 (1975).

Bunn, T.K.: vide Aldrich-Blake, F.P.G. (1971).

Buskirk,R.E.: vide Buskirk, W.H. (1974.

Buskirk, W.H.; Buskirk, R.E., and Hamilton III, W.J.: Troop-Mobilizing Behavior of Adult Male Chacma Baboons. 22 (1): 9-18 (1974).

Buss, D.H. and Cooper, R.W.: Composition of Milk fromTalapoin Monkeys. 13 (2-3): 196206(1970).

-: Composition of Squirrel Monkey Milk. 17 (4): 285-291 (1972).

Buss, D.H.; Cooper, R.W., and Wallen, K.: Composition of Lemur Milk. 26 (4): 301-305 (1976).

Buss, D. H. and Hamner III, J.E.: Supernumerary Nipples in the Baboon (Papio cynocephalus). 16(1-2): 153-158 (1971).

Busse, CD.: vide Riss, D.C (1977).

Butler, H.: Observations on the Menstrual Cycle of the Grivet Monkey (Cercopi-thecus aethíops aethiops) in the Sudan. 4 (3): 194-205 (1966).

-: Some Notes on the Distribution of Primates in the Sudan. 4 (6): 416-423 (1966).

-: Seasonal Breeding of the Senegal Galago (Galago senegalensis senegalensis) in the Nuba Mountains, Republic of the Su-

Index of Articles by Author

365

dan. 5 (3): 165-175 (1967).

-: Septic Abortion in the Senegal Bush Baby (Galago senegalensis senegalensis). 13 (2-3): 207-212 (1970). 
-: The Chronology of Embryogenesis in the Lesser Galago: A Preliminary Account. 18 (5-6): 368-378 (1972).

Butler, H. and Adam, K. R.: The Structure of the Allantoic Placenta of the Senegal Bush

Baby (Galago senegalensis senegalensis). 2 (1): 22-49 (1964).

Butler, T.M.: vide Smith, A.H. (1975).

Caballín, M.R.: vide Rubio-Goday, A. (1976).

Caldés, M.G.: vide Rubio-Goday, A. (1976).

Cambefort, Y. and Moro, F.: Cytogene-tics and Taxonomy of some South Bolivian Monkeys. 29 (4): 307-314 (1978).

Candland, D.K.; Dresdale, L.; Leyp-hart, J.; Bryan, D.; Johnson, C, and Nazar, B.: Social

Structure of the Squirrel Monkey (Saimiri scíureus, Iqui-tos): Relationships among Behavior, Heartrate, and Physical Distance. 20 (2-3): 211-240 (1973).

Candland, D.K.; Tyrrell, D.S.; Wagner, D.S., and Wagner, N.M.: Social Preference of the

Squirrel Monkey (Saimiri sciureus). 19 (6): 437-449 (1973).

Capel-Edwards, K. and Hall, D.E.: Haematological Observations on the Squirrel Monkey.

12(2): 142-160(1970).

Cartmill, M.: The Orbital Mosaic in Pro-simians and the Use of Variable Traits in

Systematics. 30 (2): 89-114 (1978).

Casimir, M. J.: Feeding Ecology and Nutrition of an Eastern Gorilla Group in the Mt.Kahuzi

Region (République du Zaire). 24 (2-3): 81-136 (1975).

Castell, R.: Communication During Initial Contact: A Comparison of Squirrel and Rhesus

Monkeys. 11 (3): 206-214 (1969).

Castell, R. and Heinrich, B.: Rank Order

in a Captive Female Squirrel Monkey Colony. 14 (3-4): 182-189 (1971).

Castell, R. und Maurus, M.: Das soge-nannte Urinmarkieren von Totenkopf-affen (Saimiri sciureus) in Abhängigkeit von umweltbedingten und emotionalen Faktoren. $6\left(3^{\wedge} \mathrm{t}\right): 170-176$ (1967).

Castenholz, A.: vide Rohen, J. W. (1967).

Castenholz, A.; Lorenz, R. und Castenholz, E.: Zur Morphometrie und Histo-logie des Auges des Springtamarins (Callimico goeldii Thomas 1904, Calli-miconidae, Primates). 29 (3): 161177 (1978).

Castenholz, E.: vide Castenholz, A. (1978).

Chalifoux, L.: vide Hunt, R.D. (1967).

Chalmers, N.R.: Group Composition, Ecology and Daily Activities of Free Living

Mangabeys in Uganda. 8 (3-4) : 247-262 (1968).

-: The Social Behaviour of Free Living Mangabeys in Uganda. 8 (3-4): 263-281 (1968).

-: The Visual and Vocal Communication of Free Living Mangabeys in Uganda. 9 (3-4): 258-

280 (1968).

-: videRowELL, T.E. (1970).

Chalmers, N.R. and Rowell, T.E.: Behaviour and Female Reproductive Cycles in a Captive

Group of Mangabeys. 14(1-2): 1-14(1971).

Chamove, A. S.: Social Behavior Comparison in Laboratory-Reared Stumptail and Rhesus

Macaques. 19 (1): 35-40 (1973).

Chamove, A. S. and Bowman, R. E.: Rank, Rhesus Social Behavior, and Stress. 26 (1): 57-66 (1976). 
Chance, M.R.A. and Jones, E.: A Protracted Startle Response to Maternal Rejection in Infants of Macaca fascicu-laris. 22 (2-3): 218-236 (1974).

Chance, M. R. A.; Jones, E., and Shostak, S.: Factors Influencing Nursing in Macaca fascicularis. 27 (1): 28-40 (1977).

Cherkovich, G.M. and Tatoyan, S.K.:

366 A Topical Guide to 'Folia Primatologica'

On the Question of Vagal Tone in Monkeys (Macaca mulatta). 17 (4): 248-254 (1972).

-: Heart Rate (Radiotelemetrical Registration) in Macaques and Baboons According to

Dominant-Submissive Rank in a Group. 20 (4): 265-273 (1973).

Cherkovich, G.M.: vide Tatoyan, S.K. (1972).

CfflARELLi, B.: Sensitivity to P.T.C. (Phe-nyl-Thio-Carbamide) in Primates. 1 (2): 8894(1963).

-: Marked Chromosome in Catarrhine Monkeys. 4 (1): 74-80 (1966).

-: vide Egozcue, J. (1967).

-: vide Egozcue, J. (1968).

Chivers, D. J.: On the Daily Behaviour and Spacing of Howling Monkey Groups. 10 (1-2):

48-102 (1969).

Chivers, D.J.; Raemaekers, J.J., and Aldrich-Blake, F.P.G.: Long-Term Observations of

Siamang Behaviour. 23 (1-2): 1-49 (1975).

Christen, A.: Haltung und Brutbiologie von Cebuella. 8 (1): $41-49$ (1968).

Christen, A.E.: vide Christen, P. (1970).

Christen, P.; Peacock, W.C.; Christen, A.E., and Wacker, W.E.C.: Urate Oxidase in Primates. 13 (1): 35-39 (1970).

Ciochon, R.L.: vide Corruccini, R.S. (1975).

Otters, R. L. van and Lasry, J. E.: Cardiovascular Function in Adult Baboons as Indicated by Standard Diagnostic Tests. 3(1): 13-21 (1965).

Clark, D. L. and Dillon, J. E.: Evaluation of the Water Incentive Method of Social

Dominance Measurement in Primates. 19 (4): 293-311 (1973).

Clark, G.C.: vide Binns, R. (1972).

Clauser, D. A.: The Numbers of Vertebrae in Three African Cercopithecine Species. 23 (4):

308-319 (1975).

Clauser, D.A.: vide Wintheiser, J.G. (1977).

Clutton-Brock, T. H.: Feeding Levels and

Feeding Sites of Red Colobus (Colobus badius tephrosceles) in the Gombe National Park. 19 (5): 368-379 (1973).

Clutton-Brock, T.H.: Activity Patterns of Red Colobus (Colobus badius tephrosceles). 21 (3-

Ф): 161-187 (1974).

Clutton-Brock, T.H.: Feeding Behaviour of Red Colobus and Black and White Colobus in

East Africa. 23 (3): 165-207 (1975).

Coe, C.L. and Rosenblum, L.A.: Annual Reproductive Strategy of the Squirrel Monkey

(Saimiri sciureus). 29 (1): 19-42(1978).

Coimbra-Filho, A.F. and Mittermeier, R. A.: New Data on the Taxonomy of the Brazilian

Marmosets of the Genus Callithrix Erxleben, 1777. 20 (4): 241-264 (1973).

Collomb, H.: vide Bert, J. (1963).

-: vide Bert, J. (1967). 
Conaway, C.H.: Adrenal Cortical Rests of the Ovarian Hilus of the Patas Monkey. 11(3): 175-180(1969).

-: vide Sorenson, M. W. (1966).

-: vide Alcalá, J.R. (1968).

Conaway, C.H. and Sade, D.S.: The Seasonal Spermatogenic Cycle in Free Ranging Rhesus Monkeys. 3 (1): 1-12 (1965).

Conroy, G. C.: vide Schòn Ybarra, M. A. (1978).

Conroy, G. C. and Wible, J. R.: Middle Ear Morphology of Lemur variegatus. Some Implications for Primate Paleontology. 29 (2): 81-85 (1978).

Conroy, G.C; Schwartz, J.H., and Simons, E. L.: Dental Eruption Patterns in Parapithecidae (Primates, Anthro-poidea). 24 (4): 275-281 (1975).

Cooper, J.E.: vide Hetherington, CM. (1975).

Cooper, R.W.: vide Pilson, M.E.Q. (1967).

-: vide Buss, D.H. (1970).

-: vide Buss, D.H. (1972)

-: vide Buss, D.H. (1976).

Index of Articles by Author

367

Coppenhaver, D.: vide Buettner-Ja-nusch, J. (1972).

Coppenhaver, D. and Buettner-Janusch, J.: Transferrins of Cercopithecinae. 13 (1): 23-34

(1970).

Cornell, R.: vide Kling, A. (1971).

Corruccini, R.S.: vide McHenry, H.M. (1975).

-: vide McHenry, H.M. (1976).

Corruccini, R.S.; Ciochon, R.L., and McHenry, H.M.: Osteometric Shape Relationships in the Wrist Joint of Some Anthropoids. 24 (4): 250-274 (1975).

Cowgill, U. M.: An Apparent Example of Displacement Behavior in the Prosimian

Perodicticuspotto.8(2): 148-149(1968).

-: Some Observations on the Prosimian Perodicticus potto. 11 (1-2): 144-150 (1969).

Cramer, D. L.: vide Maruffo, C A. (1967).

-: vide Zihlman, A.L. (1978).

Crook, J.H.: vide Deag, J.M. (1971).

Crook, J. H. and Aldrich-Blake, P.: Ecological and Behavioural Contrasts Between Sympatric

Ground Dwelling Primates in Ethiopia. 8 (3-4): 192-227 (1968).

Dail, W.G.; Norvell, J.E., and Haines, D. E.: The Intrinsic Adrenergic and Cho-linergic

Innervation of the Genitalia of Galago and Tupaia. The Penis. 16 (3-4): 221-230 (1971).

Damian, R.T.; Luker, M.F.; Greene, N.D., and Kalter, S.S.: The Occurrence of Baboon-Type

IgG Subclass Antigenic Determinants within the Order Primates. 17 (5-6): 458-474 (1972).

Davenport, R. K., jr.: The Orang-Utan in Sabah. 5 (4): 247-263 (1967).

-: videMenzel, E.W.,jr. (1970).

-: vide Menzel, E. W., jr. (1972).

David, G.F.X.; Hafez, E.S.E., and Ka-mash, M.A.: Histomorphology of Cervical and Uterine Epithelia of Crab-Eating Macaque, Macaca fascicularis. 23 (1-2): 124-134(1975).

David, G.F.X. and Ramaswami, L.S.: Unilateral Hypoplasia of the Kidney of a Female Langur Presbytis entellus entellus Dufresne. 5 (4): 312-315 (1967). 
-: Studies on Menstrual Cycles and Other Related Phenomena in the Langur (Presbytis entellus entellus). 11 (4): 300-316 (1969).

-: The Pituitary Gland of the North Indian Langur (Presbytis entellus entellus Du-frèsnej. 16 (1-2): 52-73 (1971).

Davis, P. R. and Napier, J.: A Reconstruction of the Skull of Proconsul africanus (R.S.51).

1(1): 20-28 (1963).

Dawson, P.: vide Hetherington, CM. (1975).

Day, M.H. and Iliffe, S.R.: The Contra-hens Muscle Layer in Tarsius. 24 (4): 241-249 (1975).

Day, M.H. and Napier, J.: The Functional Significance of the Deep Head of Flexor pollicis brevis in Primates. 1 (2): 122-134 (1963).

Day, M. H. and Walker, A. C: New Prosimian Remains from Early Tertiary Deposits of Southern England. 10 (1-2): 139-145 (1969).

Deag, J.M. and Crook, J.H.: Social Behaviour and 'Agonistic Buffering' in the Wild Barbary Macaque Macaca sylvana L. 15 (3-4): 183-200 (1971).

De Boer, L. E. M.: The Somatic Chromosome Complement and the Idiogram of Pithecia pithecia pithecia (Linnaeus, 1766). 23 (1-2): 149-157 (1975).

DeLannoy, C. W. jr.: vide Malinow, M. R. (1966).

-: vide Malinow, M.R. (1967).

Delort-Laval, J.: vide Hladek, CM. (1971).

Dene, H.; Goodman, M.; Prychodko, W., and Moore, G.W.: Immunodiffusion Systematics of the Primates. HI. The Strepsirhini. 25 (1): 35-61 (1976).

De Vore, I. and Lee, R.: Recent and Current Field Studies of Primates. 1 (1): 66-72 (1963).

368 A Topical Guide to 'Folia Primatologica'

De Vos, A.: vide Omar, A. (1971).

De Vos, A. and Omar, A.: Territories and Movements of Sykes Monkeys (Cerco-pithecus

mitis kolbi NeumanJ in Kenya. 16 (3-4): 196-205 (1971).

Dillyngham, L.A.: vide Heinrichs, W.L. (1970).

-: vide Antonius, J.I. (1971).

Dillingham, L.A.; Morrow, A.C., and Bronsdon, M. A.: A Comparison of the Hemograms oîMacaca mulatta, Macaca nemestrina and Papio anubis. 14 (3-4): 241-251 (1971).

Dillon, J.E.: vide Clark, D.L. (1973).

Dixon, A. F.: Effects of Testosterone on the Sternal Cutaneous Glands and Genitalia of the Male Greater Galago (Galago crassicaudatus crassicaudatus). 26 (3): 207-213 (1976)

Downing, H.J.: vide McDermid, E.M. (1973).

Doyle, G. A.: vide Pinto, D. (1974).

Doyle, G.A.; Andersson, A., and Bear-der, S.K.: Maternal Behaviour in the Lesser Bushbaby (Galago senegalensis moholi) under Semi-Natural Conditions. 11(3): 215-238 (1969).

-: Reproduction in the Lesser Bushbaby (Galago senegalensis moholi) under Semi-Natural Conditions. 14 (1-2): 15-22 (1971).

Doyle, G. A. and Bekker, T.: A Facility for Naturalistic Studies of the Lesser Bushbaby (Galago senegalensis moholi). 7 (3-4): 161-168(1967).

Doyle, G.A.; Pelleíter, A., and Bekker, T.: Courtship, Mating and Parturition in the Lesser Bushbaby (Galago senegalensis moholi) under Semi-Natural Conditions. 7 (3-4): 169-197 (1967).

Draper, W. A. and Menzel, E.W., jr.: Size and Distance of Food: Cues Influencing the Choice Behavior of Orangutans (Pongo pygmaeus). 4 (3): 186-190 (1966). 
Dresdale, L.: vide Candland, D.K. (1973).

Drickamer, L.C.: A Ten-Year Summary of Reproductive Data for Free-Ranging Macaca mulatta. 21 (1): 61-80 (1974).

Drobeck, H.P.: vide Sullivan, D.J. (1966).

Duke, K.L.: Ovogenetic Activity of the Fetal-Type in the Ovary of the Adult Slow Loris Nycticebus coucang. 7 (2): 150-154(1967).

Dukelow, W. R.: vide Jewett,D.A. (1971).

Dunbar, E.P.: vide Dunbar, R.I.M. (1974).

Dunbar, R.I.M.: vide Aldrich-Blake, F.P.G. (1971).

-: vide Coss-Custard, J.D. (1972).

Dunbar, R.I.M. and Dunbar, E.P.: Ecological Relations and Niche Separation between

Sympatric Terrestrial Primates in Ethiopia. 21 (1): 36-60 (1974).

-: Ecology and Population Dynamics of Colobus guereza in Ethiopia. 21 (3-4): 188-

208(1974).

Dunbar, R.I.M. and Nathan, M.F.: Social Organization of the Guinea Baboon, Papio papio. 17 (5-6): 321-334 (1972).

Dunn, F. L.: Patterns of Parasitism in Primates: Phylogenetic and Ecological Interpretations, with Particular Reference to the Hominoidea. 4 (5): 329-345 (1966).

Eaglen, R.H. and Boskoff, K.J.: The Birth and Early Development of a Captive Sifaka, Propithecus verreauxi coque-reli. 30 (3): 206-219 (1978)

Ecк, G. and Howell, F.C: New Fossil Cercopithecus Material from the Lower Omo Basin, Ethiopia. 18 (5-6): 325-355 (1972).

Egozcue, J.: Chromosome Dimorphism in Primates. 7 (3-4): 231-237 (1967).

-: Position of the Centromere in the Marked Acrocentric Chromosomes of Primates. 7 (3-4): 238-242 (1967).

-: Meiosis in Five Macaca Species. 11 (1-2): 1-16 (1969).

Index of Articles by Author

369

-: The Chromosomes of the Lesser Bush-baby (Galago senegalensis) and the Greater Bushbaby \{Galago crassicauda-tus). 12 (3): 236-240 (1970).

-: A Note on the Chromosomes of Aotus trivirgatus Humboldt 1812. 15 (3-4): 274-276 (1971).

-: Evolution of the Marked Chromosomes of Primates. Experimental Evidence for Pericentric Inversion. 16 (3-4): 276-281 (1971).

-: The Chromosomes of Lemurs. 17 (3): 171-176(1972).

-: XX Male Presbytis entellus A Retrospective Study. 17 (4): 292-296 (1972).

-: Evolution of the Marked Chromosomes of Primates: Experimental Evidence for Centric

Fusion. 21 (2): 148-151 (1974).

-: vide García, M. (1976).

-: vide Rubio-Goday, A. (1976).

-: vide García, M. (1978).

Egozcue, J. and Chiarelli, B.: The Idio-gram of the Lowland Gorilla (Gorilla gorilla gorilla). 5 (3): 237-240 (1967). 
Egozcue, J.; Chiarelli, B., and Sarti-Chiarelli, M.: The Somatic and Meio-tic Chromosomes of Cebuella pygmaea (Spix 1823) with Special Reference to the Behavior of the Sex Chromosomes During Spermatogenesis. 8 (1): 50-57 (1968).

Egozcue, J.; Chiarelli, B.; Sarti-Chia-relli, M., and Hagemenas, F.: Chromosome Polymorphism in the Tree Shrew (Tupaiaglis). 8 (2): 150-158 (1968).

Egozcue, J. and Perkins, E. M.: The Chromosomes of Humboldt's Woolly Monkey (Lagothrix lagothricha, Humboldt 1812 12(1): 77-80 (1970).

Egozcue, J.; Perkins, E. M., and Hagemenas, F.: Chromosomal Evolution in Marmosets, Tamarins, and Pinches. 9 (2): 81-94 (1968).

-: The Chromosomes of Saguinus fuscicol-lis illigrei (Pucheran, 1845) and Aotus trivirgatus (Humboldt, 1811). 10 (1-2): 154-159(1969).

Egozcue, J.; Perkins, E. M.; Hagemenas, F., and Ford, D. M.: The Chromosomes of Some

Platyrrhini (Callicebus, Ateles and Saimiri). 11 (1-2): 17-27 (1969).

Egozcue, J. and Vilarasau de Egozcue, M.: The Chromosome Complement of Cebus

albifrons (Erxleben 1777). 5 (4): 285-294 (1967).

Ehrlich, A.: Food-Motivated Behavior in Prosimians. 8 (1): 66-71 (1968).

-: Activity Levels in Prosimians. 8 (1): 72-76 (1968).

-: vide Fobes, J.L. (1971).

Eitzman, D. V.: Immunoglobulin Levels in the Macaca mulatta. 12 (4): 313-316 (1970).

Elliott, R.C.: Observations on a Small Group of Mountain Gorillas (Gorilla gorilla beringei). 25 (1): 12-24 (1976).

Emory, G. R.: Comparisons of Spatial and Orientational Relationships as Manifestations of Divergent Modes of Social Organization in Captive Groups oiMan-drillus sphinx and Theropithecus gelada. 24 (4): 293-314 (1975).

Epple, G.: Vergleichende Untersuchungen über Sexual- und Sozialverhalten der Krallenaffen (Hapalidae). 7 (1): 37-65 (1967).

-: Comparative Studies on Vocalization in Marmoset Monkeys (Hapalidae). 8 (1): 140(1968).

-: Maintenance, Breeding, and Development of Marmoset Monkeys (Callithri-cidae) in Captivity. 12 (1): 56-76(1970).

-: Quantitative Studies on Scent Marking in the Marmoset (Callithrixjacchus). 13 (1): 48-62 (1970).

-: Parental Behavior in Saguinus fuscicollis ssp. (Callithricidae). 24 (2-3): 221-238 (1975).

Epple, G. und Lorenz, R.: Vorkommen, Morphologie und Funktion der Ster-naldrüse bei den Platyrrhini. 7 (2): 98-126 (1967).

Erkert, H.G.: Beleuchtungsabhängiges Aktivitätsoptimum bei Nachtaffen (Ao370

A Topical Guide to 'Folia Primatologica'

tus trivirgatus). 25 (2-3): 186-192 (1976). Etter, H. F.: Terrestrial Adaptations in the Hands of Cercopithecinae. 20 (5-6): 331-350 (1973).

Fady, J.-C: Les jeux sociaux: Le compa-gnon de jeux chez les jeunes. Observations chez

Macaca irus. 11 (1-2): 134- 143 (1969).

-: vide Balzano, E. (1973).

Fairbanks, L.: An Analysis of Subgroup Structure and Process in a Captive Squirrel Monkey (Saimiri sciureus) Colony. 21 (3-4): 209-224 (1974). 
Farber, P.A.: Chromosomes of Macaca mulatta Leukocytes. 4 (6): 409-415 (1966).

-: vide Koford, C.B. (1966).

Faucheux, B.; Bertrand, M., and Bour-lière, F.: Some Effects of Living Conditions upon the Pattern of Growth in the Stumptail Macaque (Macaca arc-toides) 30 (3): 220-236 (1978).

Faulkner, M.F.: vide Hodson, H.H., jr. (1968).

Felsenfeld, O. and Wolf, R. H.: Serologi-cal Reactions with Treponemal Antigens in Nonhuman Primates and the Natural History of Treponematosis in Man. 16 (3-4): 294-305 (1971).

Felts, P.E.: vide Hodson, H.H., jr. (1968).

Ferrier, S.A.: vide Antonius, J.I. (1971).

Fineg, J.: vide Hodson, H.H., jr. (1967).

Fischer, R.B. and Nadler, R.D.: Status Interactions of Captive Female Lowland Gorillas. 28 (2): 122-133 (1977).

Fitz-Gerald, F.L.: vide Guilloud, N.B. (1967).

Fitz-Gerald, F.L.; Barfield, M.A., and Grubbs, P. A.: Food Preferences in Lowland Gorillas. 12 (3): 209-211 (1970).

Fleagle, J.G.: A Small Gibbon-Like Ho-minoid from the Miocene of Uganda. 24 (1): 1-15 (1975).

-: Locomotion and Posture of the Malayan Siamang and Implications for Hominoid Evolution. 26 (4): 245-269 (1976).

Fléchon, J.-E.; Kraemer, D.C, and Hafez, E. S. E.: Scanning Electron Microscopy of Baboon Spermatozoa. 26 (1): 24-35 (1976).

Flinn, R. M. and Oxnard, C. E.: The Relationship between Growth and the Administration of Cyanocobalamin in the Rhesus Monkey. 4 (6): $432-437$ (1966).

Flockhart, J.H.: vide Hobson, B.M. (1977).

Fobes, J.L. and Ehrlich, A.: Glucose Preferences in the Greater Galago (Ga-lago crassicaudatus) and Slow Loris (Nycticebus coucang). 16 (3-4): 306-311 (1971).

Fooden, J.: Provisional Classification and Key to Living Species of Macaques (Primates:

Macaca). 25 (2-3): 225-236 (1976).

-: Identification of the Stump-Tailed Monkey, Macaca speciosa I. Geoffroy, 1826. 5 (3): 153164 (1967).

Ford, D.J.: vide Turton, J.A. (1978).

Ford, D.M.: vide Egozcue, J. (1969).

Forni, G: vide Balzano, E. (1973).

Fox, G.J.: Some Comparisons between Siamang and Gibbon Behaviour. 18 (1-2): 122139(1972).

Freedman, L.: vide Booth, S.N. (1970).

Freemon, F.R.; McNew, J.J., and Adey, W.R.: Sleep of Unrestrained Chimpanzee:

Differences Between First and Last Rapid Eye Movement Periods. 13 (2-3): 144-149(1970).

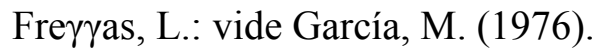

-: vide García, M. (1978).

Friedrichson, U.; R $\gamma \gamma$ ter, H., and Schmitt, J.: Genetic Variation of Aldehyde Dehydrogenase in Primates. 29 (2): 95-97 (1978).

Gallina, D. L.: vide Ausman, L. M. (1976)

García, M.; Miró, R., and Egozcue, J.:

Banding Patterns of the Chromosomes 
of Nycticebus coucang (Boddaert, 1785).

29(2): 103-106(1978).

Index of Articles by Author

371

García, M.; Miró, R.; Freitas, L., and Egozcue, J.: Banding Patterns of the Chromosomes of Cebus apella: Unstable Chromosomes and Pericentric Inversion. 29 (3): 196-205 (1978).

García, M.; Freitas, L.; Miró, R., and Egozcue, J.: Banding Patterns of the Chromosomes of Cebus albifrons. Comparative Study with Cebus apella. 25 (4): 313-319(1976).

Gartlan, J. S.: Structure and Function in Primate Society. 8 (2): 89-120 (1968).

Gartlan, J.S.: vide Goswell, M. J. (1965).

Gasser, R.F.: vide Hendrickx, A.G. (1967).

Gautier, J.-P.: vide Gautier-Hion, A. (1974).

Gautier, J.-P.: vide Gautier-Hion, A. (1976).

Gautier-Hion, A.: L'organisation sociale d'une bande de Talapoins (Miopithecus talapoin)

dans le Nord-Est du Gabon. 12(2): 116-141 (1970).

Gautier-Hion, A. et Gautier, J.-P.: Les associations polyspécifiques de Cerco-pithèques du

Plateau de M'passa (Gabon). 22 (2-3): 134-177 (1974).

Gautier-Hion, A et Gautier, J.-P.: Crois-sance, maturité sexuelle et sociale, reproduction chez les cercopithécinés fores-tiers africains. 26 (3): 165-184 (1976).

Gemzell, C.: vide Bosu, W.T.K. (1973).

Genoways, H.H.: vide Smith, J.D. (1977).

Giacometti, L.: vide Machk > a, H. (1967).

Grngerich, P.D.: Anatomy of the Temporal Bone in the Oligocene Anthropoid Apidium and the Origin of Anthropoidea. 19 (5): 329-337 (1973).

-: New Species of Eocene Primates and the Phylogeny of European Adapidae. 28 (1):|60-80 (1977).

-: Dental Variation in Early Eocene Teil-hardina belgica, with Notes on the Anterior Dentition of Some Early Tarsii-formes. 28 (2): 144-153 (1977).

-: videBowN, T.M. (1973).

Glander, K.E.: Drinking from Arboreal Water Sources by Mantled Howling Monkeys (Alouatta palliata Gray). 29 (3): 206-217 (1978).

Glaser, D.: Geschmacksschwellenwerte bei Callithricidae (Platyrrhina). 9 (3-4): 246-257

(1968).

-: Geschmacksschwellenwerte von ver-schiedenen Zuckerarten bei Callithricidae

(Platyrrhina). 13 (1): 40-47 (1970).

-: Vergleichende Untersuchungen über den Geschmackssinn der Primaten. 17 (4): 267-274

(1972).

-: Untersuchungen über die Geschmacks-wirkungen von Phenylthiocarbamid (PTC) bei

Primaten. 18 (1-2): 27-34 (1972).

-: Die Reaktion bei einigen Primaten auf zwei künstliche Süssstoffe und $7 / 8 \mathrm{O}$ dest. 18 (5-6):

433-443 (1972).

-: vide Schmid, W. (1977).

Glaser, D. und Hellekant, G.: Verhal-tens- und elektrophysiologische Experi-mente über den Geschmackssinn bei Saguinus midas tamarin (Callitrichidae). 28(1): 43-51 (1977). 
Glaser, D.; Hellekant, G.; Brouwer, J.N., and Wel, H. van der: The Taste Responses in Primates to the Proteins Thaumatin and Monellin and their Phy-logenetic Implications. 29 (1): 56-63 (1978).

Goodall, J.: Infant Killing and Cannibalism in Free-Living Chimpanzees. 28 (4): 259-282 (1977).

-: vide Riss, D. (1976).

-: vide Morris, K. (1977).

-: vide Riss, D. (1977).

Goodman, M.: vide Dene, H. (1976).

Gordon, E.B.: vide Moor-Jankowski, J. (1964).

-: vide Moor-Jankowski, J. (1965).

-: vide Wiener, A. S. (1966).

-: vide Moor-Jankowski, J. (1973).

Gordon, T. P.: vide Bernstein, I. S. (1974).

Gorste $\gamma$, F.: vide Weiss, G. (1973).

Goss-Custard, J.D.; Dunbar, R.I.M.,

372

A Topical Guide to 'Folia Primatologica'

and Aldrich-Blake, F. P. G.: Survival, Mating and Rearing Strategies in the Evolution of Primate Social Structure. 17 (1-2): 1-19 (1972).

Goswell, M. J.: vide Hall, K. R. L. (1965).

Goswell, M.J. and Gartlan, J.S.: Pregnancy, Birth and Early Infant Behaviour in the Captive Patas Monkey Erythro-cebuspatas. 3 (2-3): 189-200(1965).

Gouzoules, H.: Harassment of Sexual Behavior in the Stumptail Macaque, Macaca arctoides. 22 (2-3): 208-217 (1974).

Goy, R. W.: vide Weisbard, C. (1976).

Graham, C.E.: Chimpanzee Endometrium and Sexual Swelling during Menstrual Cycle or Hormone Administration. 19 (6): 458^168 (1973).

Grand, T. I. and Lorenz, R.: Functional Analysis of the Hip Joint in Tarsius bancanus (Horsfield, 1821) and Tarsius syrichta (Linnaeus, 1758). 9 (3-4): 161-181 (1968).

Grau, M.: vide Planas, J. (1971).

Green, R.; Whalen, R.E.; Rutley, B., and Battie, C.: Dominance Hierarchy in Squirrel Monkey (Saimiri sciureus). Role of the Gonads and Androgen on Genital Display and Feeding Order. 18 (3-4): 185-195 (1972).

Greene, N.D.: vide Damian, R.T. (1972).

Greenfield, L. O.: Note on the Placement of the Most Complete Kenyapithecus africanus Mandible. 20 (4): 274-279 (1973).

-: Taxonomic Reassessment of Two Rama-pithecus Specimens. 22 (2-3): 97-115 (1974). Groves, C. P.: Geographic Variation in the Hoolock or White-Browed Gibbon (Hy-lobates hoolock Harlan 1834J. 7 (3-4): 276-283 (1967).

-: Geographic and Individual Variation in Bornean Gibbons, with Remarks on the Systematics of the Subgenus Hylobates. 14 (3-4): 139-153 (1971).

$-:$ Notes on the Ecology and Behaviour of the Angola Colobus (Colobus angolensis P.L.Sclater, I860; in N.E.Tanzania. 20 
(1): 12-26(1973). Grubb, P.: Distribution, Divergence and Speciation of the Drill and Mandrill. 20

(2-3): 161-177 (1973). Grubbs, P.A.: vide Fitz-Gerald, F.L.

(1970). Guillon, R.: vide Balzamo, E. (1973). Guilloud, N.B.: vide McClure, H.M.

(1972). Guilloud, N.B. and Fitz-Gerald, F.L.:

Spontaneous Hyperthermia in the Gorilla. 6 (3-4): 177-179 (1967). Guthrie, C.B.: vide MoorJankowski, J.

(1965).

Habbitt, H.: vide Huang, C. C. (1969).

Hafez, E. S. E.: vide Kanagawa, H. (1971).

-: vide Jainudeen, M. R. (1972).

-: vide Kanagawa, H. (1973).

-: vide David, G.F.X. (1975).

-: vide Fléchon, J.-E. (1976).

Hagemenas, F.: vide Egozcue, J. (1968).

-: vide Egozcue, J. (1969).

Haynes, D.E.: vide Dail, W.G. (1971).

Haines, D.E.; Holmes, K.R., and Brett, I.J.: The Hemogram of the Colonized Lesser

Bushbaby (Galago senegalensis). 14 (1-2): 95-100 (1971).

Hall, B. M.: vide Turton, J. A. (1978).

Hall, D.E.: vide Capel-Edwards, K. (1970).

Hall, K.R.L.; Boelkins, R.C., and Goswell, M. J.: Behaviour of Patas Monkeys, Erythrocebus patas, in Captivity, with Notes on the Natural Habitat. 3 (1): 22-49 (1965).

Hall, K. R. L. and Mayer, B.: Social Interactions in a Group of Captive Patas Monkeys

(Erythrocebus patas). 5 (3): 213-236 (1967).

-: Hand Preferences and Dexterities of Captive Patas Monkeys. 4 (3): 169-185 (1966).

Hamilton, III W.J.: vide Tenaza, R.R. (1971).

Index of Articles by Author

373

-: videBusKiRK, W.H. (1974).

Hamner III, J.E.: vide Buss, D.H. (1971).

Hampton, J.K., jr.; Hampton, S.H., and Landwehr, B.T.: Observations on a Successful

Breeding Colony of the Marmoset, Oedipomidas oedipus. 4 (4): 265-287 (1966).

Hampton, S.H.: vide Hampton, J.K., jr. (1966).

-: vide Hsu, T.C. (1970).

Hanby, J.P.; Robertson, L.T., and Phoenix, C.H.: The Sexual Behavior of a Confined Troop of Japanese Macaques. 16(1-2): 123-143(1971).

Happold, D.C.D.: The Red Crowned Mangabey, Cercocebus torquatus, in Western Nigeria. 20 (5-6): 423-428 (1973).

Harding, R.S.O.: Ranging Patterns of a Troop of Baboons (Papio anubis) in Kenya. 25 (2-3): 143-185 (1976).

Harrington, J. E.: Development of Behavior in Lemur macaco in the First Nineteen Weeks. 29 (2): 107-128 (1978).

-: Diurnal Behavior of Lemur mongoz at Ampijoroa, Madagascar. 29 (4): 291- 302 (1978).

Hartmann-Wiesner, E.: vide Hopf, S. (1974). 
-: vide Maurus, M. (1975).

Hausfater, G.: Intergroup Behavior of Free-Ranging Rhesus Monkeys (Macaco mulatto). 18 (1-2): 78-107 (1972).

-: Tail Carriage in Baboons (Papio cyno-cephalus): Relationship to Dominance Rank and Age. 27 (1): 41-59 (1977).

Hayes, K.C.: vide Ausman, L.M. (1976).

Headley, P.M.: vide Aldrich-Blake, F.P.G. (1971).

Hearn, J.P.: vide Hobson, B. M. (1977).

Hediger, H.: Nest and Home. 28 (3): 170-187 (1977).

Hegsted, D.M.: vide Samonds, K.W. (1974).

-: vide Ausman, L.M. (1976).

Heinemann, H.: vide Lorenz, R. (1967).

Heinrich, B.: vide Castell, R. (1971).

Heinrichs, W.L. and Dillingham, L.A.: Bornean Orang-Utan Twins Born in Captivity. 13 (23): 150-154(1970).

Hellekant, G.: vide Glaser, D. (1977).

-: vide Glaser, D (1978).

Hendrickx, A.G.: vide Houston, M.L. (1968).

-: vide Baker, C.A. (1977).

Hendrickx, A.G. and Gasser, R.F.: A Description of a Diaphragmatic Hernia in a Sixteen Week Baboon Fetus (Papio sp.J. 7(1): 66-74 (1967).

Hendrickx, A.G. and Katzberg, A.A.: A Single Umbilical Artery in the Baboon. 5 (4): 295304 (1967).

Hershkovitz, P.: Taxonomic Notes on Tamarins, Genus Saguinus (Callithrici-dae, Primates), with Descriptions of Four New Forms. 4 (5): 381-395 (1966).

-: Notes on Tertiary Platyrrhine Monkeys and Description of a New Genus from the Late

Miocene of Colombia. 12 (1): 1-37 (1970).

-: Cerebral Fissural Patterns in Platyrrhine Monkeys. 13 (2-3): 213-240 (1970).

-: A New Genus of Late Oligocene Monkey (Cebidae, Platyrrhini) with Notes on Postorbital

Closure and Platyrrhine Evolution. 21 (1): 1-35(1974).

-: The Ectotympanic Bone and Origin of Higher Primates. 22 (4): 237-242 (1974).

-: Comments on the Taxonomy of Brazilian Marmosets (Callithrix, Callitrichi-dae). 24 (2-3): 137-172 (1975).

Hetherington, CM.; Cooper, J.E., and Dawson, P.: A Case of Syndactyly in the White-Lipped Tamarin Saguinus nigrícollís. 24 (1): 24-28 (1975).

Hewett-Emmett, D.: vide Barnicot, N. A.

-: vide Barnicot, N. A. (1972). (1971).

Hill, W.C.O.: Congenital Abnormalities of the Urinary Tract in Primates. 2 (2): 111-

118(1964).

-: The Maintenance of Langurs (Colobi-dae) in Captivity; Experiences and Some

Suggestions. 2 (4): 222-231 (1964).

374

A Topical Guide to 'Folia Primatologica'

-: Ontogeny of the Gut Pattern in Saimiri 11(3): 166-174(1969). 
Hill, W.C. O. and Sabater Pi, J.: Notes on Two Anomalies in Mandrills (Man-drillus sphinx Linn.j. 12 (4): 290-295 (1970).

-: Anomaly of the Hallux in a Lowland Gorilla (Gorilla gorilla gorilla Savage and WymanJ. $14\left(3^{\wedge} 1\right):$ 252-255 (1971).

Himmelheber, H.: Ein Fall von Einäugig-keit bei einem wildlebenden Colobus b. badius. 26 (3): 227-228 (1976).

Hladik, A.: vide Hladik, CM. (1971).

Hladik, CM.; Hladik, A.; Bousset, J.; Valdebouze, P.; Viroben, G. et De-lort-Laval, J.: Le regime alimentaire des Primates de Pile de Barro-Colorado (Panama). Résultats des analyses quan-titatives. 16 (1-2): 85-122 (1971).

Hobson, B.M.: Excretion of Gonadotro-phin by the Pregnant Baboon (Papio cynocephalus). 12 (2): 111-115 (1970).

-: Gonadotrophin Concentrations in the Placentae of Man, the Rhesus Monkey and the Marmoset. 18 (1-2): 35-40 (1972).

-: New Observations on the Excretion of Chorionic Gonadotrophin During Pregnancy in the Rhesus Monkey (Macaca mulatto). 18 (5-6): 463-468 (1972).

-: Chorionic Gonadotrophin in the Placenta of a Chimpanzee (Pan troglodytes). 23 (1-2): 135139 (1975).

Hobson, B.M.; Hearn, J.P.; Lunn, S.F. and Flockhart, J. H.: Urinary Excretion of Biologically Active Chorionic Gonadotrophin by the Pregnant Marmoset (Callithrix jacchus jacchus). 28 (4): 251-258 (1977).

Hudson, H.H., jr.; Lee, B.D.; Wisecup, W.G., and Fineg, J.: Baseline Blood Values of the Chimpanzee. I. The Relationship of Age and Sex and Haematol-ogical Values. 7 (1): 1-11 (1967).

Hodson, H.H., jr.; Wisecup, W.G.; Faulkner, M.F., and Felts, P.E.: Baseline Blood Values of the Chimpan-

zee. II. The Relationship of Age and Sex and Serum Chemistry Values. 8 (1): 77-86 (1968).

Hofer, H. O.: Beobachtungen an dem so-genannten «Supracommissuralen Organ» (Fuse) und am Recessus mesocoe-licus der Primaten. 5 (3): 190-200 (1967).

-: On the Organon Sublinguale in Calii-cebus (Primates, Platyrrhini). 11 (4): 268-288 (1969).

-: The Glandula Apicis Linguae in Pan troglodytes. 12(1): 38-41 (1970).

-: On the Recessus Mesocoelicus in some Primates. 15 (3-4): 249-263 (1971).

-: On the Corpus adiposum buccae (Bi-chat) in Pan troglodytes. 17 (5-6): 434-441 (1972).

-: A Comparative Study on the Oro-Nasal Region of the External Face of the Gorilla as a

Contribution to Cranio-Facial Biology of Primates. 18 (5-6): 416-432 (1972).

-: Crista sagittalis externa in the Skull of Pan troglodytes and Its Bearing on the

Reconstruction of the Head of the Robust Type of Australopithecus. 19 (6): 469-475 (1973).

-: On the Denticles of the Sublingua in Galago crassicaudatus E.Geoffrey, 1812 (Primates,

Prosimiae, Lorisiformes). 24 (2-3): 188-202 (1975).

-: Preliminary Study of the Comparative Anatomy of the External Nose of South American

Monkeys. 25 (2-3): 193-214 (1976).

-: On the Sublingual Structures of Tarsius (Prosimiae, Tarsiiformes) and Some Platyrrhine

Monkeys (Platyrrhina, Si-miae, Primates) with Casual Remarks on the Histology of the

Tongue. 27 (4): 297-314(1977).

Hofer, H.O. and Meinel, W.: A Comparative Study on the Microscopic Anatomy of the

Sublingua of Tupaia glis (Tupaiiformes). 26 (3): 229-243 (1976). 
Hofer, H. O. and Wilson, J. A.: An Endo-cranial Cast of an Early Oligocene PriIndex of Articles by Author

375

mate. 5 (1-2): 148-152 (1967).

Hoffman, R.A.: vide Hubbard, R.W. (1971).

Holmes, K.R.: vide Haines, D.E. (1971).

Holmes, R.L.: The Vascular Pattern of the Median Eminence of the Hypophysis in the Macaque. 7 (3-4): 216-230 (1967).

Hopf, S.: Study of Spontaneous Behavior in Squirrel Monkey Groups: Observations

Techniques, Recording Devices, Numerical Evaluation and Reliability Tests. 17 (5-6): 363 388 (1972).

Hopf, S.; Hartmann-Wiesner, E.; Kühl-morgen, B., and Mayer, S.: The Behavioral Repertoire of the Squirrel Monkey (Saimiri). 21 (3-4): 225-249 (1974).

Houston, M.L. and Hendrickx, A.G.: Observations on the Vasculature of the Baboon Placenta (Papio sp.) with Special Reference to the Transverse Communicating Artery. 9 (1): 68-77 (1968).

Howell, F. C.: vide Ecк, G. (1972).

Hrdy, D.B.; Barnicot, N.A., and Alper, C.A.: Protein Polymorphism in the Hanuman Langur (Presbytis entellus). 24 (2-3): 173-187 (1975).

Hrdy, S. B.: Male-Male Competition and Infanticide Among the Langurs (Presbytis entellus) of Abu, Rajasthan. 22 (1): 19-58 (1974).

Hsu, T.C. and Hampton, S.H.: Chromosomes of Callithricidae with Special Reference to an XX/'XO' Sex Chromosome System in Goeldi's Marmoset (Callimico goeldii Thomas, 1904). 13 (2-3): 183-195 (1970).

Hu, F.: vide Pasztor, L. M. (1973).

Huang, C.C.; Habbitt, H., and Ambrus, J. L.: Chromosomes and DNA Synthesis in the Stumptail Monkey (Macaca speciosa), with Special Regard to Marker and Sex

Chromosomes. 11 (1-2) 28-34 (1969).

Hubbard, R.W.; Hoffman, R.A., and Jenkins, D.: Tissue Enzyme Studies in Macaca

nemestrina Monkeys. 16 (3-4): 282-293 (1971).

Hunkeler, C.; Bourlière, F. et Bertrand, M.: Le comportement social de la Mone de Lowe

(Cercopithecus campbelli lo-wei). 17 (3): 218-236 (1972).

Hunkeler, P.: vide Struhsaker, T.T. (1971).

Hunt, R.D. and Chalifoux, L.: The He-mogram of the Tree Shrew (Tupaiaglis). 7(1): 34-36

(1967).

Hunter, W. S.: vide Zihlman, A. L. (1972).

Hurkadli, K.: vide Jayaraman, S. (1978).

Huser, H.-J.: vide Beard, M.E.J. (1970).

Huser, H.-J. and Beard, M.E.J.: Studies on Folate and Vitamin B12 Metabolism in Primates.

I. Blood and Bone Marrow Morphology, Folate and Vitamin B12 Levels. 10 (3): 172-180 (1969).

Hutchinson, T. C.: Vaginal Cytology and Reproduction in the Squirrel Monkey (Saimiri scíureus). 12 (3): 212-223 (1970).

Ibscher, L.: Geburt und frühe Entwicklung zweier Gibbons (Hylobates lar L·.). 5 (1-2): 43-69 (1967). 
Jacobs, G.H.: Brightness Preference in Nocturnal and Diurnal South American Monkeys. 28 (3): 231-240 (1977).

Jainudeen, M.R.; Hafez, E.S.E., and Kothari, L.: Histomorphology of the Cervix uteri of Toque (M. sinica) and Bonnet Macaques (M.radiata). 18 (5-6): 469-476 (1972).

Jarosch, E.: Untersuchungen über die Ein-flüsse der sozialen Organisation der

Totenkopfäffchen (Saimiri sciureus) auf das instrumentelle Lernen bzw. die selbstgewählte Reihenfolge in den Ver-suchen. 9 (2): 135-153 (1968).

Jayaraman, S.; Hurkadli, K., and Rao, S. S.: Hematological Data of the Laboratory-

Maintained Bonnet (Macaca ra-diata) and the Langur (Presbytis entellus entellus) Monkeys. 29 (2): 98-102 (1978).

376

A Topical Guide to 'Folia Primatologica'

Jenkins, D.: vide Hubbard, R.W. (1971).

Jensen, G.D.: vide Kuehn, R.E. (1965).

Jewett, D.A. and Dukelow, W.R.: Fol-licular Morphology in Macaca fascicu-laris. 16 (3-4): 216-220 (1971).

Jinks, J. L.: vide Broadhurst, P. L. (1965).

Johansson, E.D.B.: vide Bosu, W.T.K. (1973).

Johnson, C.: vide Candland, D. K. (1973).

Jolly, A.: Troop Continuity and Troop Spacing in Propithecus verreauxi and Lemur catta at Berenty (Madagascar). 17(5-6): 335-362(1972).

-: Hour of Birth in Primates and Man. 18 (1-2): 108-121(1972).

-: videKLOPFER, P.H. (1970).

Jolly, C.J. and Barnicot, N.A.: Serum and Red-Cell Protein Variations of the Celebes Black Ape. 4 (3): 206-220 (1966).

Jones, C: Notes on Ecological Relationships of Four Species of Lorisids in Rio Muni, West Africa. 11 (4): 255-257 (1969).

Jones, C. and Sabater Pi, J.: Comparative Ecology of Cercocebus albigena (Gray) and

Cercocebus torquatus (Kerr) in Rio Muni, West Africa. 9 (2): 99-113 (1968).

Jones, E.: vide Chance, M.R.A. (1974).

-: vide Chance, M.R.A. (1977).

Jones, J.K., jr.: vide Smith, J.D. (1977).

Jones, T. C.: vide Ma, N. S. F. (1975).

Jouffroy, F.K.: vide Lessertisseur, J. (1973).

Kaczera, Z.: vide Moor-Jankowski, J.

(1973). Kalter, S.S.: videDAMiAN, R.T. (1972). -: vide Kim, C.S. (1972). Kamash, M. A.: vide David, G.F.X. (1975). Kanagasuntheram, R.: vide Vu, S. (1969). -: vide Wong, W.C. (1970). -: vide Leela, K. (1971). -: vide Loo, S.K. (1971). -: vide Loo, S.K. (1972). -: vide Vu, S. (1973).

Kanagasuntheram, R. and Krishna-murti, A.: Nerve Endings in the Skin of the Foetal Hand of Slow Loris. 10 (4): 263-275 (1969).

Kanagasuntheram, R.; Krishnamurti, A., and Ahmed, M.: Nerve Terminations in the Digital Skin of the Hand in Some Lorisoids. 12 (1): $42-55$ (1970). 
Kanagawa, H.; Hafez, E.S.E.; Mori, J.; Kurosawa, T., and Kothari, L.: Cyclic Changes in Cervical Mucus and LH Levels in the Bonnet Macaque (Macaca radiata). 19 (2-3): 208-217 (1973).

Kanagawa, H.; Hafez, E.S.E., and Na-war, M.: The Chromosomes of the Crab-eating Macaque (Macaca fasci-cularis). 16 (3-4): 270-275 (1971).

Kantaria, P. M.: The Blood Supply of the Heart in Different Monkey Species. On the Types of Myocardial Blood Supply. 16(3-4): 231-247 (1971).

Katz, C.C.: vide Szalay, F.S. (1973).

Katzberg, A.A.: Changing Dynamics in the Thyroid Follicles of the Baboon, Papio anubis. 8 (1): 58-65 (1968).

-: vide Hendrickx, A.G. (1967).

Katzberg, A. A. and Ungerleider, G. K.: Changing Dynamics in the Germinal Centers of the Spleen of the East Africa Baboon, Papio anubis. 7 (1): 75-80 (1967).

Kaufmann, I.C.: vide Rosenblum, L.A. (1966).

-: vide Rosenblum, L.A. (1967).

-: videSTYNES, A.J. (1968).

Kaufmann, J. H.: Studies on the Behavior of Captive Tree Shrews (Tupaia glis). 3(1): 50-74 (1965).

Kavanagh, M.: The Diet and Feeding Behaviour of Cercopithecus aethiops tantalus. 30 (1): 30-63 (1978).

Kavanau, J. L. and Peters, C. R.: Twilight Zeitgebers, Weather, and Activity of Nocturnal Primates. 26 (1): 67-79 (1976).

Keeling, M.E.: vide McClure, H.M. (1972).

Index of Articles by Author

377

Kelly, M.G.: vide O'Gara, R.W. (1967).

Kemp, G.E.: vide Schlitter, D.A. (1973).

Kerber, W.T.: vide O'Gara, R.W. (1967).

Keesel, U.: Vergleichend-morphologische und histologische Untersuchungen am Integument des Schwanzes von Tarsius syrichta (L., 1758) und Tarsius bancanus (Horsfield, 1821). 9 (34): 182-215 (1968).

Kim, C.S. and Kalter, S.S.: Unilateral Renal Aplasia in an African Baboon (Papio sp.j. 17 (12): 157-159 (1972).

King, C.T.G.: vide Barrow, M. V. (1969).

Klein, L.L.: Observations on Copulation and Seasonal Reproduction of Two Species of

Spider Monkeys, Ateles belze-butft and A. geoffroyi. 15 (3-4): 233-248 (1971).

-: vide Rondinelli, R. (1976).

Klima, M.: Ossa suprasternalia der Prima-ten und die Spezialanpassungen des Manubrium sterni bei den Brüllaffen (Alouatta). 17 (5-6): 421-433 (1972).

Kling, A. and Cornell, R.: Amygdalec-tomy and Social Behavior in the Caged Stump-tailed Macaque (Macaca spe-ciosa). 14 (3-4): 190-208 (1971).

Klopfer, P. H.: Discrimination of Young in Galagos. 13 (2-3): 137-143 (1970).

Klopfer, P. H. and Jolly, A.: The Stability of Territorial Boundaries in a Lemur Troop. 12 (3): 199-208 (1970).

Knezevic, A.L. and McNulty, W.P.: Tuberculosis in Lemur mongoz. 6 (1-2): 153-159(1967). 
Knobil, E.: vide Weiss, G. (1973).

Koford, C. B.; Farber, P. A., and Windle, W. F.: Twins and Teratisms in Rhesus Monkeys. 4 (3): 221-226 (1966).

Kothari, L.: vide Jainudeen, M. R. (1972).

Kothari, L.: vide Kanagawa, H. (1973).

Kraemer, D. C.: vide Fléchon, J.-E. (1976).

Krishnamurti, A.: The External Morphology of the Brain of the Slow Loris Nycticebus

coucang coucang. 4 (5): 361-380 (1966).

-: The Cerebral Arteries of Nycticebus coucang coucang. 8 (2): 159-168 (1968).

-: vide Kanagasuntheram, R. (1969).

-: vide Kanagasuntheram, R. (1970).

-: vide Vu, S. (1973).

Kühlmorgen, B.: vide Hopf, S. (1974).

-: vide Maurus, M. (1975).

Kuehn, R. E.; Jensen, G. D., and Morrill, R. K.: Breeding Macaca nemestrina: A Program of Birth Engineering. 3 (4): 251-262 (1965).

Kuhn, H.-J.: Ein angeborener Unterkiefer-Defekt bei Procolobus badius badius (Kerr, 1792). 1 (3-4): 172-177 (1963).

-: Zur Kenntnis von Bau und Funktion des Magens der Schlankaffen (Colobinae). 2(4): 193221 (1964).

Kumamoto, A.T.: vide Bogart, M.H. (1977).

-: vide Bogart, M.H. (1978).

Kumar, T. C. A.: Structure of the Pituitary Gland and Cytophysiology of the

Adenohypophysis in the Slender Loris Loris tardigradus lydekkerianus Cabr. 6 (3-4): 220235 (1967).

Kummer, H.: Distribution of Interindivid-ual Distances in Patas Monkeys and Gelada

Baboons. Species and Sex Differences. 21 (3-4): 153-160 (1974).

Kummer, H. and Kurt, F.: Social Units of a Free-living Population of Hamadryas Baboons. 1(1): 4-19 (1963).

Kurosawa, T.: vide Kanagawa, H. (1973).

Kurt, F.: vide Kummer, H. (1963).

Lahiri, R.K. and Southwick, C.H.: Parental Care in Macaca sylvana. 4 (4): 257-264 (1966).

Lai, L.Y.C.: Transferrins in Macaca irus. 17 (3): 193-201 (1972).

Lamey, D.: vide Michejda, M. (1971).

Lancaster, J.B.: Play-mothering: The Relations between Juvenile Females and Young Infants among Free-ranging Vervet Monkeys (Cercopithecus aethi-ops). 15 (3-4): 161-182 (1971).

378

A Topical Guide to 'Folia Primatologica'

Landwehr, B.T.: vide Hampton, J.K., (1966).

Lang, C. M.: vide Brumback, R. A. (1971).

Lange, V. und Schmitt, J,: Das Serum-eiweissbild der Primaten unter beson-derer

Berücksichtigung der Haptoglo-bine und Transferrine. 1 (3-4): 208-250 (1963).

Larson, C; Sutton, D., and Lindeman, R.C.: Muscle Spindles in Nonhuman Primate

Laryngeal Muscles. 22 (4): 315-323 (1974). 
La Salle, M.: Interrelationship of Blood Groups between Rhesus Macaques (Macaca mulatta) and Celebes Ape (Macaca niger). 20 (2-3): 95-105 (1973).

Lasley, B.L.: vide Bogart, M.H. (1977).

Lasry, J.E.: vide Otters, R. L. van (1965).

Layton, W.: vide Benirschke, K. (1969).

Lee, B.D.: vide Hodson, H.H., jr. (196).

Lee, R.: vide De Vore, I. (1963).

Leela, K. and Kanagasuntheram, R.: Craniopharyngeal Canal and Pharyn-geal Hypophysis in the Siamang Gibbon (Symphalangus syndactylus). 14 (1-2): 118-122(1971).

Leyphart, J.: vide Candland, D. K. (1973).

Lemmon, W.B.: vide Savage, E.S. (1973).

Lemmon, W. B. and Allen, M. L.: Continual Sexual Receptivity in the Female Chimpanzee

(Pan troglodytes). 30 (1): 80-88 (1978).

Lerner, R.P.: vide Smith, I. (1971).

Lessertisseur, J. et Jouffroy, F. K.: Tendances locomotrices des primates tra-duites par les

proportions du pied. L'adaptation à la bipédie. 20 (2-3): 125-160(1973).

Leutenegger, W.: Beziehungen zwischen der Neugeborenengrösse und dem Se-

xualdimorphismus am Becken bei simi-schen Primaten. 12 (3): 224-235 (1970).

-: Encephalization in Australopithecines: a New Estimate. 19 (1): 9-17 (1973).

-: Maternal-Fetal Weight Relationships in Primates. 20 (4): 280-293 (1973).

-: Neonatal-Maternal Weight Relation-

ship in Macaques: An Example of Intrageneric Scaling. 27 (2): 152-159 (1977).

Levine, S.: vide Mendoza, S.P. (1978).

Lewis, CM.: vide Brink, A.J. (1970).

Lewis, O.J.: The Contrasting Morphology Found in the Wrist Joints of Semi-brachiating

Monkeys and Brachiating Apes. 16 ( $\left.3^{\wedge} \ddagger\right): 248-256$ (1971).

Lindeman, R. C.: vide Larson, C. (1974).

Lippert, W.: Beobachtungen zum Schwan-gerschafts- und Geburtsverhalten beim Orang-

Utan (Pongo pygmaeus) im Tierpark Berlin. 21 (2): 108-134 (1974).

Lisowski, F.P.: Angular Growth Changes and Comparisons in the Primate Talus. 7 (2): 81-97

(1967).

Lochner, A.: vide Brink, A. J. (1970).

Loo, S.K.: A Comparative Study of the Nasal Fossa of Four Nonhuman Primates. 20 (5-6):

410-422 (1973).

-: Comparative Study of the Histology of the Nasal Fossa in Four Primates. $21\left(3^{\wedge} \ddagger\right): 290$ 303 (1974).

Loo, S.K. and Kanagasuntheram, R.: The Nasal Fossa of Tupaia glis and Nycticebus coucang. 16 (1-2): 74-84 (1971).

Loo, S.K.; Kanagasuntheram, R., and Tock, E.P.C.: A Comparative Histo-chemical Study of the Mucins of the Nasal Fossa in Four Primates. 17 (4): 275-284 (1972).

Lorenz, R.: Waschen bei zwei Arten der Gattung Presbytis (Cercopithecoidea, Primates). 4

(3): 191-193 (1966).

-: Goeldi's Monkey Callimico goeldii Thomas 1904 Preying on Snakes. 15 (1-2): 133 -

142(1971).

-: vide Epple, G. (1967).

-: vide Grand, T.I.(1968). 
-: vide Castenholz, A. (1978).

Lorenz, R.; Anderson, C.O., and Mason, W.A.: Notes on Reproduction in Captive Squirrel Monkeys (Saimiri sciureus). 19 (4): 286-292 (1973).

Lorenz, R. und Heinemann, H.: Beitrag

Index of Articles by Author

379

zur Morphologie und körperlichen Jugendentwicklung des Springtamarin Callimico goeldii (Thomas, 1904). 6 (1-2): 1-27 (1967).

Low, R.J. and Benirschke, K.: Chromosome Study of a Marmoset Hybrid. 8 (3-4): 180-191 (1968).

Lowe, E.: vide Mendoza, S.P. (1978).

Love, J. A.: A Note on the Birth of a Baboon (Papio anubis). 29 (4): 303-306 (1978).

Loy, J.: Peri-Menstrual Sexual Behavior Among Rhesus Monkeys. 13 (4): 286-297 (1970).

-: Changes in Facial Color Associated with Pregnancy in Patas Monkeys. 22 (4): 251-257

(1974).

Luckett, W.P.: Cladistic Relationships among Primate Higher Categories: Evidence of the

Fetal Membranes and Placenta. 25 (4): 245-276 (1976).

Luker, M.F.: videDAMiAN, R.T. (1972).

Lunn, S. F.: vide Hobson, B. M. (1977).

Luscombe, G.: vide Reynolds, V. (1971).

Ma, N.S.F. and Jones, T.C.: Added Heterochromatin Segments in Chromosomes of Squirrel Monkeys (Saimiri sciureus). 24 (4): 282-292 (1975).

McArthur, J.W.; Ovadia, J.; Smith, O. W., and Bashir-Farahmand, J.: The Menstrual Cycle of the Bonnet Monkey (Macaca radiata). Changes in Cervical Mucus Secretion, Vaginal

Cytology, Sex Skin and Urinary Estrogen Excretion. 17 (1-2): 107-121 (1972).

McClure, H.M.; Keeling, M.E., and Guilloud, N.B.: Hematologic and Blood Chemistry Data for the Orangutan (Pongo pygmaeus). 18 (3-4): 284-299(1972).

-: Hematologic and Blood Chemistry Data for the Gorilla (Gorilla gorilla). 18 (3-4): 300-316 (1972).

-: Hematologic and Blood Chemistry Data for the Chimpanzee (Pan troglodytes). 18 (5-6): 444-462 (1972).

McDermid, E. M. and Ananthakrishnan, R.: Red Cell Enzymes and Serum Proteins of

Cercopithecus aethiops (South African Green Monkey). 17 (1-2): 122-131 (1972).

McDermid, E. M.; Vos, G.H., and Downing, H.J.: Blood Groups, Red Cell Enzymes and

Serum Proteins of Baboons and Vervets. 19 (4): 312-326 (1973).

McGrew, W.C.: vide Tutin, C.E.G. (1973).

McHenry, H. M.: vide Corruccini, R. S. (1975).

McHenry, H.M. and Corruccini, R.S.: Distal Humerus in Hominoid Evolution. 23 (3): 227244 (1975).

-: Affinities of Tertiary Hominoid Femora. 26(2): 139-150(1976).

Machida, H. and Giacometti, L.: The Anatomical and Histochemical Properties on the Skin of the External Genitalia of the Primates. 6 (1-2): 48-69 (1967).

Machida, H.; Perkins, E., and Giacometti, L.: The Anatomical and Histochemical Properties of the Tongue of Primates. 5 (4): 264-279 (196).

Mack, D.S.: vide Brown, K. (1978). 
McKenna, M.C.: Paleontology and the Origin of the Primates. 4 (1): 1-25 (1966).

McNew, J. J.: vide Freemon, F.R. (1970).

McNulty, W.P.: vide Knezevic, A.L. (1967).

MacPhee, R.D.E.: Ontogeny of the Ecto-tympanic-Petrosal Plate Relationship in Strepsirhine Prosimians. 27 (4): 245-283 (1977).

Maller, O.: Quality and Intensity of Sugar Solutions as Determinants of Ingestion by the Rhesus Monkey (Macaca mulatto). 20 (1): $72-77$ (1973).

Malinow, M. R.: Artherosclerosis in Subhuman Primates. 3 (4): 277-300 (1965).

-: An Electrocardiographic Study of Macaca mulatto. 4 (1): 51-65 (1966).

-: videSTAHL, W.R. (1967).

380

A Topical Guide to 'Folia Primatologica'

Malinow, M.R. and DeLannoy, C.W.: The Electrocardiogram of Cynopithecus niger. 4 (1): 66-73 (1966).

-: The Electrocardiogram of Macaca fuscata. 7 (3-4): 284-291 (1967).

Mann, P.: vide Angst, R. (1971).

Maples, W.R.: vide Moreno-Black, G. (1977).

Marler, P.: Vocalizations of East African Monkeys. I. Red Colobus. 13 (2-3): $81-91$ (1970).

Marriott, B. M. and Salzen, E. A.: Facial Expressions in Captive Squirrel Monkeys (Saimiri sciureus). 29 (1): 1-18 (1978).

Marsden, H.M.: Behavior Between two Social Groups of Rhesus Monkeys Within two Tunnel-Connected Enclosures. 8 (3-4): 240-246 (1968).

Martino, A.: vide Bert, J. (1967).

Maruffo, C. A. and Cramer, D. L.: Congenital Renal Malformations in Monkeys. 5 (4): 305311 (1967).

Mason, W.A.: Comparative Studies of Social Behavior in Callicebus and Saimiri: Behavior of Male-Female Pairs. 22(1):1-8(1974).

-: Comparative Studies of Social Behavior in Callicebus and Saimiri: Strength and Specificity of Attraction between Male-Female Cagemates. 23 (1-2): 113-123 (1975).

Mason, W.A.: vide Randolph, M.C. (1969).

-: vide Lorenz, R. (1973).

Maurer, R.: vide Biegert, J. (1972).

Maurus, M.: vide Castell, R. (1967).

Maurus, M.; Kühlmorgen, B.; Hart-mann-Wiesner, E., and Pruscha, H.: An Approach to the Interpretation of the Communicative Meaning of Visual Signals in Agonistic Behavior of Squirrel Monkeys. 23 (3): 208-226 (1975).

Mayer, B.: vide Hall, K.R.L. (1966).

-: vide Hall, K.R.L. (1967).

Mayer, S.: vide Hopf, S. (1974).

Mayer, W.: vide Talmage-Riggs, G. (1972).

Mazur, A.: Effects of Testosterone on Status in Primate Groups. 26 (3): 214-226 (1976).

Meier, R.J.: Considerations on Function in Macaque Dermatoglyphics. 20 (2-3): 112124(1973).

Meinel, W.: vide Hofer, H. (1976). 
Meinel, W. und Woehrmann-Repenning, A.: Zur Morphologie und Histologie des Geruchsorgans von Tupaia glis (Diard 1820). 20 (4): 294-311 (1973).

Mendel, F.: Postural and Locomotor Behavior of Alouatta palliata on Various Substrates. 26 (1): 36-53 (1976).

Mendoza, S.P.; Lowe, E., and Levine, S.: Social Organization and Social Behavior in Two Subspecies of Squirrel Monkeys (Saimiri sciureus). 30 (2): 126-144 (1978).

Menzel, E.W., jr.: Communication about the Environment in a Group of Young

Chimpanzees. 15 (3-4): 220-232 (1971).

-: Spontaneous Invention of Ladders in a Group of Young Chimpanzees. 17 (1-2): 87-

106(1972).

-: Further Observations on the Use of Ladders in a Group of Young Chimpanzees. 19 (6): 450-457 (1973).

-: vide Draper, W.A. (1966).

-: vide Moody, M.I. (1976).

Menzel, E. W., jr.; Davenport, R.K., and Rogers, CM.: The Development of Tool Using in

Wild-Born and Restriction-Reared Chimpanzees. 12 (4): 273-283 (1970).

-: Protocultural Aspects of Chimpanzees' Responsiveness to Novel Objects. 17 (3): 161170(1972).

Menzel, E.W., jr.; Premack, D., and Woodruff, G.: Map Reading by Chimpanzees. 29 (4): 241-249 (1978).

Mertl, A. S.: Olfactory and Visual Cues in Social Interactions of Lemur catta. 26 (2): 151-161 (1976).

Michael, R.P. and Wilson, M.: Changes

Index of Articles by Author

381

in the Sexual Behaviour of Male Rhesus Monkeys (M.mulatta) at Puberty. Comparisons with the Behaviour of Adults. 19 (5): 384-403 (1973).

Michejda, M. and Lamey, D.: Flexion and Metric Age Changes of the Cranial Base in the Macaca mulatto. I. Infant and Juveniles. 14 (1-2): 84-94 (1971).

Middleton, E.H.: vide Morrison, P. (1967).

Milton, K.: Urine-Rubbing Behavior in the Mantled Howler Monkey Alouatta palliata. 23 (12): 105-112 (1975).

Miró, R.: vide García, M. (1976).

-: vide Garcia, M. (1978).

Mitchell, G.D.: Persistent Behavior Pathology in Rhesus Monkeys Following Early Social Isolation. 8 (2): 132-147 (1968).

Mittermeier, R.A.: Locomotion and Posture in Ateles geoffroyi and Ateles paniscus. 30 (3):

161-193 (1978).

-: vide Coimbra-Filho, A.F. (1973).

Moody, M.I. and Menzel, E.W., jr.: Vocalizations and their Behavioral Contexts in the

Tamarin Saguinus fuscicollis. 25 (2-3): 73-94 (1976).

Moore, C.P.: vide Parer, J.T. (1968).

Moore, G.W.: vide Dene, H. (1976).

Moore, J.K. and Moore, R.Y.: A Comparative Study of the Superior Olivary Complex in the Primate Brain. 16 (1-2): 35-51 (1971). 
Moore, R. Y.: vide Moore, J.K. (1971).

Moor-Jankowski, J.: vide Wiener, A. S. (1966).

Moor-Jankowski, J.: vide Wiener, A.S. (1977).

Moor-Jankowski, J.; Socha, W.W.; Wiener, A.S., and Plonski, H.: Chimpanzee Simian-Type Blood Groups: Reproducibility of Formerly Described Antisera and Demonstration of New Blood Groups Oc and Pcl. 28 (3): 216-230(1977).

Moor-Jankowski, J.; Wiener, A.S., and Gordon, E. B.: Blood Groups of Apes

and Monkeys. III. The M-N Blood Factors of Apes. 2 (3): 129-148 (1964).

Moor-Jankowski, J.; Wiener, A. S.; Gordon, E.B., and Guthrie, C.B.: Simian Blood Groups. A 'New' Blood Factor, Aba, of Celebes Black Ape Red Cells Demonstrated with Rabbit Antisera. 3 (4): 245-250 (1965).

Moor-Jankowski, J.; Wiener, A.S., and Socha, W. W.: A New Taxonomic Tool. II.

Serological Differences between Baboons and Geladas Demonstrated by CrossImmunization. 22 (1): 59-71 (1974).

Moor-Jankowski, J.; Wiener, A.S.; Socha, W.W.; Gordon, E.B., and Kaczera, Z.: Blood Group Homo-logues in Orangutans and Gorillas of the Human Rh-Hr and the Chimpanzee CE-F Systems. 19 (5): 360-367 (1973).

Moreno-Black, G. and Maples, W.R.: Differential Habitat Utilization of Four

Cercopithecidae in a Kenyan Forest. 27 (2): 85-107 (1977).

Mori, J.: vide Kanagawa, H. (1973).

Moro, F.: vide Cambefort, Y. (1978).

Morrill, R.K.: vide Kuehn, R.E. (1965).

Morris, K. and Goodall, J.: Competition for Meat between Chimpanzees and Baboons of the Gombe National Park. 28 (2): 109-121 (1977).

Morrison, P. and Middleton, E. H.: Body Temperature and Metabolism in the Pigmy

Marmoset. 6 (1-2): 70-82 (1967).

Morrow, A.C.: vide Dillingham, L.A. (1971).

Nadler, R.D.: vide Fischer, R.B. (1977).

-: vide Tilford, B. L. (1978).

Nadler, R.D. and Tilford, B.L.: Agonistic Interactions of Captive Female Orang-Utans with Infants. 28 (4): 298-305 (1977).

Nagel, U.: A Comparison of Anubis Baboons, Hamadryas Baboons and Their Hybrids at a Species Border in Ethiopia.

382 A Topical Guide to 'Folia Primatologica'

19 (2-3): 104-165 (1973)

Napier, J.: vide Davis, P.R. (1963).

-: vide Day, M.H. (1963).

Napier, J. R. and Walker, A. C.: Vertical Clinging and Leaping - a Newly Recognized

Category of Locomotor Behaviour of Primates. 6 (3-4): 204-219 (1967).

Nass, G. G.: Intra-Group Variations in the Dental Eruption Sequence of Macaca fuscata fuscata. 28 (4): 306-314 (1977).

Nathan, M.F.: vide Dunbar, R.I.M. (1972).

Nathan, T.: vide Rosenblum, L.A. (1967).

Nawar, M.: vide Kanagawa, H. (1971).

Nazar, B.: vide Candland, D.K. (1973).

Nelson, J.: vide Rosenblum, L.A. (1967). 
Neville, M. K.: The Population Structure of Red Howler Monkeys (Alouatta seni-culus) in Trinidad and Venezuela. 17 (1-2): 56-86(1972).

-: Social Relations within Troops of Red Howler Monkeys (Alouatta seniculus). 18 (1-2): 47 77 (1972).

Niemitz, C: A Contribution to the Postnatal Behavioral Development of Tar-sius bancanus, Horsfield, 1821. Studied in Two Cases. 21 (3-4): 250-276 (1974).

Nishida, T.: The Bark-Eating Habits in Primates, with Special Reference to Their Status in the Diet of Wild Chimpanzees. 25 (4): 277-287 (1976).

Noback, C.R.: vide Shryver, J.E. (1967).

Norvell, J.E.: vide Dail, W.G. (1971).

Nute, P.E. and Buettner-Janusch, J.: Serum Transferrins of Pongidae: Pan, Pongo, and Hylobates. 8 (3-4): 282-289 (1968).

-: Genetics of Polymorphic Transferrins in the Genus Lemur. 10(3): 181-194(1969).

Nute, P.E.; Buettner-Janusch, V., and Buettner-Janusch, J.: Genetic and Biochemical Studies of Transferrins and Hemoglobins of Galago. 10 (4): 276-287 (1969).

O'Gara, R.W.; Kelly, M.G., and Ker-ber, W. T.: A Spontaneous Metastasiz-

ing Carcinoma of the Gallbladder in a Rhesus Monkey 6 (3-4): 284-291 (1967).

Omar, A.: vide De Vos, A. (1971).

Omar, A. and De Vos, A.: The Annual Reproductive Cycle of an African Monkey (

Cercopithecus mitis kolbi Neumann. 16 (3-4): 206-215 (1971).

Ommaya, A.K.: vide Rosen, S.I. (1972).

Oppenheimer, E.C.: vide Oppenheimer, J.R. (1973).

Oppenheimer, R.R. and Oppenheimer, E. C.: Preliminary Observations of Ce-bus

nigrivittatus (Primates: Cebidae) on the Venezuelan Llanos. 19 (6): 409-436 (1973).

Ovadia, J.: vide McArthur, J. W. (1972).

Owens, N. W.: vide Rhine, R. J. (1972).

Oxnard, C.E.: Vitamin B12 Nutrition in some Primates in Captivity. 4 (6): 424-431 (1966).

-: vide Flinn, R.M. (1966).

-: videSpiCER, E.J.F. (1967).

Pace, N.: vide Rahlmann, D. F. (1967).

-: vide Smith, A. H. (1975).

Parer, J.T. and Moore, C.P.: Respiratory Characteristics of the Blood of the Baboon, Gibbon, and Chimpanzee. 9 (2): 154-159(1968).

Pasztor, L.M. and Hu, F.: Chromosomal Evolution in a Rhesus Cell Line. 19 (1): 28-34

(1973).

Pawlik, M.: Über die Variabilität der prä-basialen Kyphose bei der Gattung Cercopithecus. 5

(3): 201-212 (1967).

Peacock, W.C.: vide Christen, P. (1970).

Pegram, V.: vide Bert, J. (1969).

-: vide Bert, J. (1972).

Pelletier, A.: vide Doyle, G.A. (1967).

Perkins, E.: vide Machida, H. (1967).

Perkins, E. M.: vide Egozcue, J. (1968).

-: vide Egozcue, J. (1969).

-: vide Egozcue, J. (1970).

Peters, C.R.: vide Kavanau, J.L. (1976). 
Petter-Rousseaux, A.: vide Bourlière, F. (1966).

Index of Articles by Author

383

Petter-Rousseaux, A. et Bourlière, F.: Persistence des phénomènes d'ovogé-nèse chez

Tadulte de Daubentonía mada-gascariensis (Prosimii, Lemuriformes). 3 (4): 241-244 (1965).

Phillips, J.: vide Schlitter, D.A. (1973).

Phoenix, C.H.: vide Hanby, J.P. (1971).

Pickering, D.E.: Reproduction Characteristics in a Colony of Laboratory Confined Mulatta

Macaque Monkeys. 8 (3-4): 169-179 (1968).

Pickering, D.E. and Van Wagenen, G.: The 'Golden' Mulatta Macaque (Macaca mulatta):

Developmental and Reproduction Characteristics in a Controlled Laboratory Environment. 11

(3): 161-166(1969).

Pilbeam, D.R.: vide Simons, E.L. (1965).

Pilson, M.E.Q. and Cooper, R.W.: Composition of Milk from Galago crassicau-datus. 5 (1-

2): 88-91 (1967).

Pinto, D.; Doyle, G.A., and Bearder, S. K.: Patterns of Activity in Three Nocturnal Prosimian

Species, Galago sene-galensis moholi, G. crassicaudatus umbro-sus, and Microcebus murinus murinus, under Semi-Natural Conditions. 21 (2): 135-147(1974).

Planas, J.: Haptoglobins in Chimpanzees and Gorillas. 13 (2-3): 177-182 (1970).

Planas, J. and Grau, M.: Serum Chemistry in the Chimpanzee and the Gorilla. 15 (1-2): 77-87 (1971).

Plentl, A.A.; Dede, J.A., and Grey, R.M.: Adenocarcinoma of the Large Intestine in a

Pregnant Rhesus Monkey (Macaca mulatta). Report of a Case. 8 (3-4): 307-313 (1968).

Plonski, H.: vide Moor-Jankowski, J. (1977).

Ploog, D.: vide Bowden, D. (1967).

-: vide Talmage-Riggs, G. (1972).

Ploog, D.W.; Blitz, J., and Ploog, F.: Studies on Social and Sexual Behavior of the Squirrel

Monkey (Saimiri sciu-reus). 1(1): 29-66(1963).

Ploog, F.: vide Ploog, D. W. (1963).

Plutchik, R.: The Study of Social Behavior in Primates. 2 (2): 67-92 (1964).

Poirier, F. E.: The Nilgiri Langur (Presby-tis johnii) Troop: Its Composition, Structure, Function and Change. 10 (1-2): 20-47 (1969).

-: Behavioral Flexibility and Intertroop Variation Among Nilgiri Langurs (Pres-bytis johnii) of South India. 11 (1-2): 119-133 (1969).

-: Dominance Structure of the Nilgiri Langur (Presbytis johnii) of South India. 12 (3): 161 186 (1970).

-: The Communication Matrix of the Nilgiri Langur (Presbytis johnii) of South India. 13 (23): 92-136 (1970).

-: The St. Kitts Green Monkey (Cercopi-thecus aethiops sabaeus): Ecology, Population

Dynamics, and Selected Behavioral Traits. 17 (1-2): $20-55$ (1972).

Poirier, F.E. and Smith, E.O.: The Crab-Eating Macaques (Macaca fascicularis) of Angaur Island, Palau, Micronesia. 22 (4): 258-306 (1974).

Prasad, K.N.: Critical Observations on the Fossil Anthropoids from the Siwalik System of India. 10 (4): 288-317 (1969).

Prasad, M. R. N.: vide Ramakrishna, P.A. (1967). 
Premack, D.: vide Menzel, E.W., jr. (1978).

Preuschoft, H.: Body Posture and Mode of Locomotion in Early Pleistocene Hominids. 14 (34): 209-240 (1971).

Pruscha, H.: vide Maurus, M. (1975).

Prychodko, W.: vide Dene, H. (1976).

Raemaekers, J.: Changes through the Day

in the Food Choice of Wild Gibbons. 30

(3): 194-205 (1978). Raemaekers, J.J.: vide Chivers, D.J.

(1975). Rahlmann, D. F.: The Hemodynamics of

the Pig-tailed Monkey (Macaca nemes-

trina). 13(1): 1-10(1970). Rahlmann, D.F.; Pace, N, and Barn-

384

A Topical Guide to 'Folia Primatologica'

stein, N.J.: Hematology of the Pig-Tailed Monkey, Macaca nemestrina. 5 (4): 280-284

(1967).

Ramakrishna, P. A. and Prasad, M.R. N.: Changes in the Male Reproductive Organs of Loris tardigradus lydekkerianus (Cabrera). 5 (3): 176-189 (1967).

Ramaswami, L.S.: vide David, G.F.X. (1967).

-: vide David, G.F.X. (1969).

-: vide David, G.F.X. (1971).

Ramírez, C: vide Yunis, E. (1977).

-: vide Yunis, E.J. (1976).

-: vide Torres de Caballero, O.M. (1976).

Ramírez, Z.E.: vide Yunis, E.J. (1976).

Randolph, M.C. and Brooks, B. A.: Conditioning of a Vocal Response in a Chimpanzee through Social Reinforcement. 5 (1-2): 70-79 (1967).

Randolph, M.C. and Mason, W.A.: Effects of Rearing Conditions on Distress Vocalizations in Chimpanzees. 10 (1-2): 103-112(1969).

Ransom, B.S.: vide Ransom, T.W. (1971).

Ransom, T.W. and Ransom, B.S.: Adult Male-Infant Relations among Baboons \{Papio anubis). 16(3-4): 179-195(1971).

Rao, S.S.: vide Jayaraman, S. (1978).

Reynolds, V.: An Outline of the Behaviour and Social Organisation of Forest-living

Chimpanzees. 1 (2): 95-102 (1963).

-: On the Identity of the Ape Described by Tulp 1641. 5 (1-2): 80-87 (1967).

Reynolds, V. and Luscombe, G.: On the Existence of Currently Described Subspecies in the Chimpanzee (Pan troglodytes). 14(3-4): 129-138 (1971).

Rhine, R. J.: The Order of Movement of Yellow Baboons (Papio cynocephalus). 23 (1-2): $72-$ 104 (1975).

Rhine, R.J. and Owens, N.W.: The Order of Movement of Adult Male and Black Infant Baboons (Papio anubis) Entering and Leaving a Potentially Dangerous Clearing. 18 (34): 276-283 (1972).

Rhine, R.J. and Westlund, B.J.: The Nature of a Primary Feeding Habit in Different Age-SexClasses of Yellow Baboons (Papio cynocephalus). 30 (1): 64-79 (1978).

Rich, K.: vide Rosen, S.I. (1972). 
Richard, A.: A Comparative Study of the Activity Patterns and Behavior of Alou-atta villosa and A teles geoffroyi. 12 (4): 241-263 (1970).

-: Intra-Specific Variation in the Social Organization and Ecology of Propithe-cus verreauxi. 22 (2-3): 178-207 (1974).

Ryesen, A.H.: vide Rumbaugh, D.M. (1972).

Riss, D.C. and Busse, CD.: Fifty-Day Observation of a Free-Ranging Adult Male

Chimpanzee. 28 (4): 283-297 (1977).

Riss, D. and Goodall, J.: Sleeping Behavior and Associations in a Group of Captive

Chimpanzees. 25 (1): 1-11 (1976).

-: The Recent Rise to the Alpha-Rank in a Population of Free-Living Chimpanzees. 27 (2):

134-151 (1977).

R $\pi$ ter, H.: vide Friedrichson, U. (1978).

Roberts, J.A. and Seibold, H.R.: The Histology of the Primate Urethra. 14 (1-2): 59-69

(1971).

Roberts, J.A. and Wolf, R.H.: Hydro-nephrosis of Pregnancy: a Naturally Occurring Disorder in Non-human Primates Closely Resembling that in Man. 15(1-2): 143-147(1971).

Roberts, M.S.: The Annual Reproductive Cycle of Captive Macaca sylvana. 29 (3): 229-235 (1978).

Roberts, P.: Social Interactions of Galago crassicaudatus. 14(34): 171-181 (1971).

Robertson, L.T.: vide Hanby, J.P. (1971).

Rogers, CM.: vide Menzel, E.W. (1970).

-: vide Menzel, E.W., jr. (1972).

Rohen, J.W. und Castenholz, A.: Über die Zentralisation der Retina bei Pri-maten. 5 (1-2): 92447 (1967).

Rohles, F. H., jr.: Performance by a Rhesus Monkey on Three Randomly Presented Index of Articles by Author

385

Skill Sequences. 7 (3-4): 208-215 (1967).

-: Social Entrainment of the Feeding Behavior in Monkeys. 15 (1-2): 58-64 (1971).

Rondinelli, R. and Klein, L. L.: An Analysis of Adult Social Spacing Tendencies and Related Sozial Interactions in a Colony of Spider Monkeys (Ateles geoffroyi) at the San Francisco

Zoo. 25 (2-3): 122-142 (1976).

Rose, K.D.: vide Bown, T.M. (1976).

Rose, R. M.: vide Bernstein, I. S. (1974).

Rosen, S. I.: Twin Gorilla Fetuses. 17 (1-2): 132-141 (1972).

Rosen, S.I.; Rich, K., and Ommaya, A.K.: Note on Blonde Chimpanzee. 18 (1-2): 41-46

(1972).

Rosenblum, LA.: vide Stynes, A. J. (1968).

-: vide Coe,C.L. (1978).

Rosenblum, LA.; Kaufman, I.C., and Stynes, A.J.: Some Characteristics of Adult Social and Autogrooming Patterns in two Species of Macaque. 4 (6): 438-451 (1966).

Rosenblum, L.A.; Nathan, T.; Nelson, J., and Kaufman, I.C.: Vaginal Corni-fication Cycles in the Squirrel Monkey (Saimirisciurea). 6 (1-2): 83-91 (1967).

Rothe, H.: Beobachtungen zur Geburt beim Weissbüscheläffchen (Callithrix jacchus

Erxleben, 1777). 19 (4): 257-285 (1973). 
Rowell, T.E.: The Effect of Temporary Separation from Their Group on the Mother Infant Relationship of Baboons. 9 (2): 114-122 (1968).

-: Long-Term Changes in a Population of Ugandan Baboons. 11 (4): 241-254 (1969).

-: Variation in Age at Puberty in Monkeys. 27 (4): 284-296 (1977).

-: Reproductive Cycles of the Talapoin Monkey (Miopithecus talapoin). 28 (3): 188-202

(1977).

-: vide Chalmers, N.R. (1971).

-: vide Wolfheim, J.H. (1972).

Rowell, T.E. and Chalmers, N.R.: Re-

productive Cycles of the Mangabey Cercocebus albigena. 12 (4): 264-272 (1970).

Rubio-Gosay, A.; Caballín, M.R.; Cal-dés, M.G., and Egozcue, J.: Comparative Study of the Banding Patterns of the Chromosomes of Cercopithecidae. I. Subfamily Papinae: Macaca fascicularis and Papio sphinx. 26 (4): 306-309 (1976).

Rudran, R.: The Reproductive Cycles of Two Subspecies of Purple-Faced Lan-gurs

(Presbytis senex) with Relation to Environmental Factors. 19 (1): 41-60 (1973).

-: Adult Male Replacement in One-Male Troops of Purple-Faced Langurs (Presbytis senex senex) and its Effect on Population Structure. 19 (2-3): 166-192 (1973).

Rumbaugh, D.M.: vide Arnold, R.C. (1971).

Rumbaugh, D.M. and Arnold, R.C: Learning: A Comparative Study of Lemur and Cercopithecus. 14(3-4): 154-160(1971).

Rumbaugh, D.M.; Riesen, A.H., and Wright, S. C.: Creative Responsiveness to Objects: A Report of a Pilot Study with Young Apes. 17 (5-6): 397-^103 (1972).

Rumbaugh, D.M. and Steinmetz, G.T.: Discrimination Reversal Skills of the Lowland Gorilla (Gorillag.gorilla). 16 (1-2): 144-152(1971).

Rutley, B.: vide Green, R. (1972).

Saayman, G.S.: The Menstrual Cycle and Sexual Behaviour in a Troop of Free-Ranging Chacma Baboons (Papio ursi-nus). 12 (2): 81-110 (1970).

-: Behaviour of the Adult Males in a Troop of Free-Ranging Chacma Boboons (Papio ursinus). 15 (1-2): 36-57 (1971).

-: Grooming Behaviour in a Troop of Free-Ranging Chacma Baboons (Papio ursinus). 16

$\left(3^{\wedge} 1\right): 161-178$ (1971).

386

A Topical Guide to 'Folia Primatologica'

-: Effects of Ovarian Hormones upon the Sexual Skin and Mounting Behaviour in the Freeranging Chacma Baboon (Pa-pio ursinus). 17 (4): 297-303 (1972).

Sabater Pi, J.: An Albino Lowland Gorilla from Rio Muni, West Africa, and Notes on its Adaptation to Captivity. 7 (2): 155-160 (1967).

-: Contribution to the Ecology of Man-drillus sphinx Linnaeus 1758 of Rio Muni (Republic of Equatorial Guinea). 17 (4): 304-319 (1972).

-: Notes on the Ecology of Five Lorisi-formes of Rio Muni. 18 (1-2): 140-151 (1972).

-: Contribution to the Ecology of Colobus polykomos satanas (Waterhouse, 1838) of Rio

Muni, Republic of Equatorial Guinea. 19 (2-3): 193-207 (1973).

-: vide Jones, C. (1968).

-: vide Hill, W. C.O. (1970).

-: vide Hill, W.C.O. (1971). 
Sade, D. S.: Seasonal Cycle in Size of Testes of Free-Ranging Macaca mulatta. 2 (3): 171180 (1964).

-: Sociometrics of Macaca mulatta. I. Linkages and Cliques in Grooming Matrices. 18(3-4): 196-223(1972).

-: vide Conaway, C.H. (1965).

Salzen, E. A.: vide Marriott, B. M. (1978).

Samonds, K. W.; Ausman, L. M., and Heg-sted, D.M.: Hematological Development of the Cebus Monkey (Cebus albi-frons and apella). 22 (1): $72-79$ (1974).

Sarti-Chiarelli, M.: vide Egozcue, J. (1968).

Sauer, E.G.F.: Mother-Infant Relationship in Galagos and the Oral Child-Transport Among Primates. 7 (2): 127-149 (1967).

Savage, D.E. and Waters, B.T.: A New Omomyid Primate from the Wasatch Formation of Southern Wyoming. 30 (1): 1-29 (1978).

Savage, E.S.; Temerlin, J.W., and Lem-mon, W.B.: Group Formation among Captive Mother-Infant Chimpanzees

(Pan troglodytes). 20 (5-6): 453-473 (1973).

Schlitter, D.A.; Phillips, J., and Kemp, G.E.: The Distribution of the White-collared

Mangabey, Cercocebus torqua-tus, in Nigeria. 19 (5): 380-383 (1973).

Schm $\gamma d$, W. and Glaser, D.: The Banded Karyotype of Saguinus midas tamarin Link, 1975

(Callitrichidae, Primates). 28 (2): 154-158 (1977).

Schmidt, R. E.: Colobomas in Non-human Primates. 14 (3-4): 256-268 (1971).

Schmitt, J.: vide Lange, V. (1963).

-: vide Friedrichson, U. (1978).

Schön, M.A.: The Anatomy of the Resonating Mechanism in Howling Monkeys. 15 (1-2): 117-132 (1971).

Schön, M.A. and Zyemer, L.K.: Wrist Mechanism and Locomotor Behavior of Dryopithecus (Proconsul) africanus. 20(1): 1-11 (1973).

Schön Ybarra, M.A. and Conroy, G.C.: Non-Metric Features in the Ulna of Aegyptopithecus, Alouatta, A teles, and Lagothrix. 29 (3): 178-195 (1978).

Schrier, A.M.: Learning-Set Formation and Transfer in Rhesus and Talapoin Monkeys. 17 (56): 389-396 (1972).

Schultz, A.H.: Relations Between the Lengths of the Main Parts of the Foot Skeleton in Primates. 1 (3-4): 150-171 (1963).

-: A Gorilla with Exceptionally Large Teeth and Supernumerary Premolars. 2 (3): 149160(1964).

-: Observations on the Acetabulum of Primates. 11 (3): 181-199 (1969).

-: Polydactylism in a Siamang. 17(4): 241 - 247 (1972).

-: Age Changes, Variability and Generic Differences in Body Proportions of Recent

Hominoids. 19 (5): 338-359 (1973).

-: The Rise of Primatology in the Twentieth Century. 26 (1): 5-23 (1976).

Schultz, M. und Starck, D.: Neue Beo-bachtungen und Überlegungen zur Pa-thologie des Primatenschädels. Ein Bei-

Index of Articles by Author

387

trag zur 'Gundu'-Frage. 28 (2): 81-108 (1977). 
Schusterman, R.J.: vide Bernstein, I.S. (1964).

Schwartz, J.H.: Re-Evaluation of the Morphocline of Molar Appearance in the Primates. 23 (4): 290-307 (1975).

-: vide Conroy, G.C. (1975).

Seay, B.: Maternal Behavior in Primiparous and Multiparous Rhesus Monkeys. 4 (2): 146168 (1966).

Seibold, H.R.: vide Roberts, J.A. (1971).

Seiler, R.: Besonderheiten an der Gesichts-muskulatur von Daubentonia madagasca/·1/8rt5

-: Die Fazialismuskeln von Perodicticus potto und Nycticebus coucang. 23 (4): 275-289 (1975).

Seligsohn, D.: vide Szalay, F. S. (1977).

Severson, A.: vide Tappen, N.C. (1971).

Shostak, S.: vide Chance, M. R. A. (1977).

Shryver, J.E. and Noback, C.R.: Color Vision in the Tree Shrew (Tupaia glis). 6 (3-4): 161169 (1967).

Silk, J. B.: Patterns of Food Sharing among Mother and Infant Chimpanzees at Gombe

National Park, Tanzania. 29 (2): 129-141 (1978).

Simons, E.: vide Andrews, P. (1977).

Simons, E.L.: vide Tattersall, I.M. (1969).

-: vide Conroy, G.C. (1975).

Simons, E.L. and Pilbeam, D.R.: Preliminary Revision of the Dryopithecinae (Pongidae, Anthropoidea). 3 (2-3): 81-152 (1965).

Sirianni, J.E.; Swindler, D.R., and Tar-rant, L.H.: Somatometry of Newborn

Macacanemestrina. 24(1): 16-23 (1975).

Smith, A. A.: Major Salivary Glands of the Philippine Tarsier. 10 (1-2): 113-130 (1969).

Smith, A.H.; Butler, T. M., and Pace, N.: Weight Growth of Colony-Reared Chimpanzees. 24 (1): 29-59 (1975).

Smith, E.O.: vide Poyrier, F.E. (1974).

Smith, I.: Comparative Biochemistry of the Primates. I. Amino Acid Patterns in the Blood and Urine. 14 (1-2): 101-109 (1971).

Smith, I. and Lerner, R.P.: Comparative Biochemistry of the Primates. II. The Indole

Compounds of Primate Blood and Urine. 14 (1-2): 110-117 (1971).

Smith, J.D.; Genoways, H.H., and Jones, J.K., jr.: Cranial and Dental Anomalies in Three Species of Platyrrhine Monkeys from Nicaragua. 28 (1): 1-42 (1977).

Smith, O.W.; vide McArthur, J.W. (1972).

Socha, W.W.: vide Moor-Jankowski, J. (1973).

-: vide Moor-Jankowski, J. (1974).

-: vide Moor-Jankowski, J. (1977).

-: vide Wiener, A.S. (1977).

Sorenson, M.W.: vide Williams, H.W. (1969).

Sorenson, M.W. and Conaway, C.H.: Observations on the Social Behavior of Tree Shrews in Captivity. 4 (2): 124-145 (1966).

Southwick, C.H.: vide Lahiri, R.K. (1966).

Spatz, W.B.: Zur Ontogenese der Bulla tympanica von Tupaia glis Diard 1820 (Prosimiae, Tupaiiformes). 4 (1): 26-50 (1966). 
-: Die Ontogenese der Cartilago meckeli und der Symphysis mandibularis bei Tupaia glis (Diard, 1820). Die distale Verknöcherung des Meckelschen Knor-pels als funktionelle Anpassung an den Saugakt. 6 (3-4): 180-203 (1967).

-: Die Bedeutung der Augen für die sagit-tale Gestaltung des Schädels von Tarsius (Prosimiae, Tarsiiformes). 9 (1): 22-40 (1968).

Spicer, E.J.F. and Oxnard, C.E.: Some Haematological Changes During Pregnancy in the Rhesus Monkey (Macaca mulatto). 6 (3-4): 236-242 (1967).

Sprankel, H.: Untersuchungen an Tarsius. I. Morphologie des Schwanzes nebst 388

A Topical Guide to 'Folia Primatologica'

ethologischen Bemerkungen. 3 (2-3): 153-188 (1965).

-: Observation on Growth Structure of the Nail in Hominoidea. 10 (3): 161-171 (1969).

Stahl, W.R. and Malinow, M.R.: A Survey of Physiological Measurements in Macaca

mulatta. 7 (1): 12-33 (1967).

Starck, D.: vide Schultz, M. (1977).

Starin, E.D.: Food Transfer by Wild Titi Monkeys (Callicebus torquatus torqua t tus). 30 (2): 145-151 (1978).

Staton, R.D.: vide Brumback, R.A. (1971).

Steffek, A.J.: vide Barrow, M.V. (1969).

Steininger, F.: Ein weiterer Zahn von Dryopithecus (Dry.) fontani darwini Abel, 1902

(Mammalia, Pongidae) aus dem Miozän des Wiener Beckens. 7 (3-4): 243-275 (1967).

Steinmetz, G.T.: vide Rumbaugh, D.M. (1971).

Stinson, J. M.: Intrarenal Arterial Patterns in Nonhuman Primates. 14 (1-2): 70-79 (1971).

Struhsaker, T.T.: Correlates of Ecology and Social Organization Among African

Cercopithecines. 11 (1-2): 80-118(1969).

Struhsaker, T.T. and Hunkeler, P.: Evidence of Tool-using by Chimpanzees in the Ivory

Coast. $15\left(3^{\wedge} \ddagger\right): 212-219$ (1971).

Stynes, A. J.: vide Rosenblum, L.A. (1966).

Stynes, A. J.; Rosenblum, L. A., and Kaufman, I.C.: The Dominant Male and Behavior

Within Heterospecific Monkey Groups. 9 (2): 123-134 (1968).

Suarez, B.K. and Bernor, R.: Growth Fields in the Dentition of the Gorilla. 18 (5-6): 356-367

(1972).

Sullivan, D.J. and Drobeck, H.P.: True Hermaphrodism in a Rhesus Monkey. 4 (4): 309-317

(1966).

Suomi, S.J.: vide Baldwin, D.V. (1974).

Sussman, R. W. and Tattersall, I.: Cycles of Activity, Group Composition, and Diet of Lemur mongoz mongoz Linnaeus

1766 in Madagascar. 26 (4): 270-283

(1976). Sutton, D.: vide Larson, C. (1974). Swindler, D. R.: vide Sirianni, J. E. (1975).

Swindler, D.R. and Tarrant, L.H.: The

Topography of the Premaxillary-Frontal

Region in Nonhuman Primates. 19 (1):

18-23 (1973). Szalay, F. S.: New Paleocene Primates and

a Diagnosis of the New Suborder

Paromomyiformes. 19 (2-3): 73-87 
(1973). -: New Genera of European Eocene

Adapid Primates. 22 (2-3): 116-133

(1974). -: A New Species and Genus of Early

Eocene Primate from North America.

22 (4): 243-250 (1974). -: Where to Draw the Nonprimate-

Primate Taxonomic Boundary. 23 (1-2):

158-163 (1975). -: vide Wilson, J.A. (1976). Szalay, F.S. and Katz, C.C.: Phylogeny

of Lemurs, Galagos and Lorises. 19

(2-3): 88-103 (1973). Szalay, F. S. and Seligsohn, D.: Why Did

the Strepsirhine Tooth Comb Evolve?

27(1): 75-82 (1977). Szalay, F.S. and Wilson, J.A.: Basi-

cranial Morphology of the Early Tertiary Tarsiiform Rooneyia from Texas. 25

(4): 288-293 (1976).

Talmage-Riggs, G.: vide Anschel, S. (1977).

Talmage-Riggs, G. and Anschel, S.: Homosexual Behavior and Dominance Hierarchy in a Group of Captive Female Squirrel Monkeys (Saimiri sciureus). 19 (1): 61-72 (1973).

Talmage-Riggs, G.; Winter, P.; Ploog, D., and Mayer, W.: Effect of Deafening on the Vocal Behavior of the Squirrel Monkey (Saimiri sciureus). 17 (5-6): 404-420 (1972).

Tappen, N.C.: vide Wintheiser, J.G. (1977).

Index of Articles by Author

389

Tappen, N. C. and Severson, A.: Sequence of Eruption of Permanent Teeth and Epiphyseal Union in New World Monkeys. 15 (3-4): 293-312 (1971).

Tarrant, L.H.: vide Swindler, D.R. (1973).

-: vide Sirianni, J.E. (1975).

Tatoyan, S.K.: vide Cherkovich, G.M. (1972).

-: vide Cherkovich, G.M. (1973).

Tatoyan, S.K. and Cherkovich, G.M.: The Heart Rate in Monkeys (Baboons and Macaques) in Different Physiological States Recorded by Radio-telemetry. 17 (4): 255-266 (1972).

Tattersall, I.: Revision of the Subfossil Indriinae. 16 (3-4): 257-269 (1971).

-: The Functional Significance of Airo-rhynchy in Megaladapis. 18 (1-2): 20-26 (1972).

-: vide Sussman, R.W. (1976).

Tattersall, I. M. and Simons, E. L.: Notes on Some Little-Known Primate Fossils from India. 10 (1-2): 146-153 (1969).

Taub, D. M.: Geographic Distribution and Habitat Diversity of the Barbary Macaque Macaca sylvanus L. 27 (2): 108-133 (1977).

Teleki, G.: Group Response to the Accidental Death of a Chimpanzee in Gombe National

Park, Tanzania. 20 (2-3): 81-94 (1973).

Temerlyn, J.W.: vide Savage, E.S. (1973).

Tenaza, R.R.: Territory and Monogamy Among Kloss' Gibbons (Hylobates klossii) in Siberut Island, Indonesia. 24 (1): 60-80 (1975).

Tenaza, R.R. and Hamilton III, W.J.: Preliminary Observations of the Menta-wai Islands Gibbon, Hylobates klossii. 15 (3-4): 201-211 (1971). 
The Regional Primate Research Center. Program of the Animal Resources Branch, Division of Research Facilities and Resources, National Institutes of Health, Bethesda 14, Md., USA. September 1963. 2 (2): 124-128 (1964).

Thommen, D.: vide Angst, W. (1977).

Thompson, P.: vide Williams, H. W. (1969).

Thoryngton, R.W., jr.: Observations of the Tamarin Saguinus midas. 9 (1): $95-98$ (1968).

Tigges, J.: On Color Vision in Gibbon and Orang-Utan. 1 (3-4): 188-198 (1963).

-: On Visual Learning Capacity, Retention and Memory in Tupaia glis Diard 1820. 2 (4): 232-245 (1964).

-: Ein experimenteller Beitrag zum sub-kortikalen optischen System von Tupaia glis. 4 (2): 103-123 (1966).

Tigges, J. and Tigges, M.: The Accessory Optic System and Other Optic Fibres of the Squirrel Monkey. 10 (4): 245-262 (1969).

Tigges, M.: vide Tigges, J. (1969).

Tilford, B.L.: vide Nadler, R.D. (1977).

Tilford, B.L. and Nadler, R.D.: Male Parental Behavior in a Captive Group of Lowland Gorillas (Gorilla gorilla gorilla). 29 (3): 218-228 (1978).

Tocк, E.P.C.: vide Loo, S.K. (1972).

Torres de Caballero, O. M.: vide Yunis, E.J. (1976).

-: vide Yunis, E. (1977).

Torres de Caballero, O. M.; Ramirez, C, and Yunis, E.: Genus Cebus Q- and G-Band Karyotypes and Natural Hybrids. 26(4): 310-321 (1976).

Turton, J.A.; Ford, D.J.; Bleby, J.; Hall, B.M., and Whiting, R.: Composition of the Milk of the Common Marmoset (Callithrixjacchus) and Milk Substitutes Used in Hand-rearing Programmes, with Special Reference to Fatty Acids. 29 (1): 64-79 (1978).

Tutin, C.E.G. and McGrew, W.C.: Chimpanzee Copulatory Behaviour. 19 (4): 237-256 (1973).

Tyrrell, D.S.: vide Candland, D.K. (1973).

Uhlmann, K.: Die Mm. adductores femoris der niederen Altweltaffen (Cercopithe-cidae). 6 (1-2): 131-152 (1967).

390

A Topical Guide to 'Folia Primatologica'

-: Die phylogenetische Entwicklung der Hüft- und Oberschenkelmuskulatur der Primaten. 15 (1-2): 88-116 (1971).

Ungerleider, G. K.: vide Katzberg, A. A. (1967).

Valdebouze,P. : vide Hladik, C. M. (1971).

Vandenbergh, J. G.: Feeding, Activity and Social Behavior of the Tree Shrew, Tupaia glis, in a Large Outdoor Enclosure. 1 (3-4): 199-207 (1963).

Van Horn, R.N.: Vibrissae Structure in the Rhesus Monkey. 13 (4): 241-285 (1970).

-: Primate Breeding Season: Photoperi-odic Regulation in Captive Lemur catta. 24 (2-3): 203-220 (1975).

Van Wagenen, G.: Fertility of the Colony-Born Male Macaque. 5 (4): 241-246 (1967).

-: vide Pickering, D.E. (1969).

Varley, M. A. and Vessey, S. H.: Effects of Geographic Transfer on the Timing of Seasonal Breeding of Rhesus Monkeys. 28(1): $52-59$ (1977). 
Vessey, S.H.: Interactions Between Free-Ranging Groups of Rhesus Monkeys. 8 (3-4): 228239 (1968).

-: vide Wilson, A.P. (1968).

-: vide Varley, M.A. (1977).

Vu, S. and Kanagasuntheram, R.: Inner-vation of Oral Tissues in Some Primates. 11 (4): 289299 (1969).

Vu, S.; Kanagasuntheram, R., and Krishnamurti, A.: Sensory Nerve Terminations in the Oral Tissues of Some Pongidae. 20 (4): 312-320 (1973).

Vilarasau de Egozcue, M.: vide Egozcue, J. (1967).

Viroben, G.: vide Hladik, CM. (1971).

Vogel, C.: Sulcus mylohyoideus, Foramen mandibulae und Sulcus retrotoralis bei Ponginen und Hylobatiden. 1 (2): 103-121 (1963).

Vogt, J.L.: The Social Behavior of a Marmoset (Saguinus fuscicollis) Group. III.

Spatial Analysis of Social Structure. 29 (4): 250-267 (1978). Vos, G.H.: vide McDermid,

E.M. (1973).

Wacker, W.E.C.: vide Christen, P. (1970).

Wagner, D.S.: vide Candland, D.K. (1973).

Wagner, N.M.: vide Candland, D.K. (1973).

Walker, A.C.: vide Napier, J. R. (1967).

-: vide Day, M.H. (1969).

Wallen, K.: vide Buss, D.H. (1976).

Waser, P.M.: Postreproductive Survival and Behavior in a Free-Ranging Female Mangabey. 29 (2): 142-160 (1978).

Waters, B.T.: vide Savage, D.E. (1978).

Weick, R.F.: vide Weiss, G. (1973).

Weisbard, C. and Goy, R.W.: Effect of Parturition and Group Composition on Competitive Drinking Order in Stump-tail Macaques (Macaca arctoides). 25 (2-3): 95-121 (1976).

Weiss, G.; Weick, R. F.; Knobil, E.; Wol-man, S.R., and Gorstern, F.: An X-O Anomaly and Ovarian Dysgenesis in a Rhesus Monkey. 19 (1): 24-27 (1973).

Wel, H. van der: vide Glaser, D. (1978).

Welker, C.: Aufzucht des Halbaffen Galago crassicaudatus E. Geoffrey, 1812 (Lorisi-formes:

Galagidae) im Familienver-band. 18 (5-6): 379-389 (1972).

-: Ethologische Bedeutung des Harnwa-schens von Galago crassicaudatus E. Geoffrey, 1812

(Lorisiformes: Galagidae). 20 (5-6): 429-452 (1973).

-: Fishing Behaviour in Galago crassicaudatus E. Geoffrey 1812 (Prosimiae; Lorisiformes;

Galagidae). 26 (4): 284-291 (1976).

Westlund, B.J.: vide Rhine, R.J. (1978).

Whalen, R.E.: vide Green, R. (1972).

Whiting, R.: vide Turton, J.A. (1978).

Whybrow, P. J. and Andrews, P.: Restoration of the Holotype of Proconsul nyanzae. 30 (2):

115-125 (1978).

Index of Articles by Author

391

Wible, J.R.: vide Conroy, G.C. (1978).

Wiener, A.S.: vide Moor-Jankowski, J. (1964). 
-: vide Moor-Jankowski, J. (1965).

-: vide Moor-Jankowski, J. (1973).

-: vide Moor-Jankowski, J. (1974).

-: vide Moor-Jankowski, J. (1977).

Wiener, A.S.; Moor-Jankowski, J., and Gordon, E.B.: Blood Groups of Apes and Monkeys. VI. Further Studies on the Human Blood Group Factors Ai Bl H\&nå Lé in Monkeys. 4 (2):

81-102 (1966).

Wiener, A.S.; Socha, W.W., and Moor-Jankowski, J.: Erythroblastosis Models. II. MaternoFetal Incompatibility in Chimpanzee. 27 (1): 68-74 (1977).

Wiersema, H.D.: vide Brehme, H. (1973).

Wiggins, R.C.: vide Buettner-Janusch, J. (1970).

Willenborg, D.O.: vide Brumback, R. A. (1973).

Williams, H.W.; Sorenson, M.W., and Thompson, P.: Antiphonal Calling of the Tree Shrew Tupaia palawanensis. 11 (3): 200-205 (1969).

Wilson, A.P. and Vessey, S. H.: Behavior of Free-Ranging Castrated Rhesus Monkeys. 9(1): 1-14 (1968).

Wilson, C.C.: Spatial Factors and the Behavior of Nonhuman Primates. 18 (3-4): 256-275

(1972).

Wilson, C.C. and Wilson, W.L.: The Influence of Selective Logging on Primates and some other Animals in East Kalimantan. 23 (4): 245-274 (1975).

Wilson, J.A.: A New Primate from the Earliest Oligocene, West Texas. Preliminary Report. 4 (3): 227-248 (1966).

-: vide Hofer,H.O. (1967).

-: vide Szalay, F.S. (1976).

Wilson, J.A. and Szalay, F.S.: New Adapid Primate of European Affinities from Texas. 25

(4): 294-312 (1976).

Wilson, M.: vide Michael, R.P. (1973).

Wilson, W. L.: vide Wilson, C. C. (1975).

Windle, W.F.: vide Koford, C.B. (1966).

Winter, P.: The Variability of Peep and Twit Calls in Captive Squirrel Monkeys (Saimiri sciureus). 10 (3): 204-215 (1969).

-: Dialects in Squirrel Monkeys: Vocalization of the Roman Arch Type. 10 (3): 216-

229(1969).

-: vide Bowden, D. (1967).

-: vide Talmage-Riggs, G. (1972).

Wintheiser, J.G.; Clauser, D.A., and Tappen, N. C.: Sequence of Eruption of Permanent

Teeth and Epiphyseal Union in Three Species of African Monkeys. 27(3): 178-197(1977).

Wisecup, W.G.: vide Hodson, H.H., jr. (1967).

-: vide Hodson, H.H., jr. (1968).

Woehrmann-Repenning, A.: vide Mernel, W. (1973).

Wolf, R.H.: Placenta Previa in a Patas Monkey (Erythrocebuspatas). 14(1-2): 80-83 (1971).

-: vide Felsenfeld, O. (1971).

-: vide Roberts, J.A. (1971).

Wolfheim, J.H.: A Quantitative Analysis of the Organization of a Group of Captive Talapoin Monkeys (Miopithe-cus talapoin). 27 (1): 1-27 (1977). 
Wolfheim, J.H. and Rowell, T.E.: Communication among Captive Talapoin Monkeys

(Miopithecus talapoin). 18 (3-4): 224-255 (1972).

Wolman, S. R.: vide Weiss, G. (1973).

Wong, W. C. and Kanagasuntheram, R.: Effects of Median Nerve Injury on Some Digital

Tissues of the Hand of the Macaque (Macacafascícularís). 13 (1): 63-73 (1970).

Woodruff, G.: vide Menzel, E.W., jr. (1978).

Wright, P.C: Home Range, Activity Pattern, and Agonistic Encounters of a Group of Night

Monkeys (Aotus trivir-gatus) in Peru. 29 (1): 43-55 (1978).

Wright, S.C.: vide Rumbaugh, D.M. (1972).

392

A Topical Guide to 'Folia Primatologica'

Yunis, E.: vide Torres de Caballero, O.M. (1976).

Yunis, E.; Torres de Caballero, O.M., and Ramirez, C.: Genus Aotus Q- and G-Band

Karyotypes in Natural Hybrids. 27 (3): 165-177 (1977).

Yunis, E. J.; Torres de Caballero, O. M.; Ramírez, C, and Ramírez, Z., E.: Chromosomal

Variations in the Primate Alouatta seniculus seniculus. 25 (2-3): 215-224 (1976).

Zapfe, H.: Lebensbild von Megaladapis edwardsi (Grandidier). Ein Rekonstruk-tionsversuch. 1 (3-4): 178-187 (1963).

Zenker, A.: Die pathologischen Verände-

rungen am Unterkiefer von Megaladapis edwardsi G. Grandidier. 3 (1): $75-80$ (1965).

Ziemer, L.K.: vide Schön, M. A. (1973).

Zihlman, A. L. and Cramer, D. L.: Skeletal Differences between Pygmy (Pan pa-niscus) and Common Chimpanzees (Pan troglodytes). 29 (2): 86-94 (1978).

Zihlman, A.L. and Hunter, W.S.: A Biochemical Interpretation of the Pelvis of Australopithecus. 18 (1-2): 1-19 (1972).

Zingeser, M. R.: Dentition of Brachyteles arachnoides with Reference to Alouat-tine and Ateline Affinities. 20 (5-6): 351-390 (1973). 